Review Article

Shengnan Li, Dong Du, Lei Zhang, Xiaoguo Song, Yongguang Zheng, Guoqin Huang, and Weimin Long*

\title{
A review on filler materials for brazing of carbon-carbon composites
}

https://doi.org/10.1515/rams-2021-0007

Received Jan 15, 2020; accepted Apr 23, 2020

Abstract: It is needed to join $\mathrm{C} / \mathrm{C}$ composite to other materials since its individual use is limited. Brazing is a method to join $\mathrm{C} / \mathrm{C}$ composite that has been studied most, maturest and most widely used in recent decades. The quality of a brazed joint is largely determined by the intermediate layer material. It is significant to choose filler materials reasonably. $\mathrm{C} / \mathrm{C}$ composite is difficult to be wetted by common brazing filler materials. Moreover, there is a large difference in the coefficient of thermal expansion between $\mathrm{C} / \mathrm{C}$ composite and metals. At present, there is no brazing filler alloy exclusively recommended for commercial $\mathrm{C} / \mathrm{C}$ composites and metal brazing. Usually, active elements are added into filler metals to improve the wettability of them on $\mathrm{C} / \mathrm{C}$ composite surface. The existing research includes Al-based, Agbased, $\mathrm{Cu}$-based, Ti-based, Ni-based brazing filler metals, and so on. In addition, various particle reinforced composite filler materials and stress buffer metal interlayer added composite filler materials have been studied for brazing $\mathrm{C} / \mathrm{C}$ composite. The summarization of the overview on the application of intermediate filler metals is made in this paper. The basic reference basis is provided for the subsequent brazing filler metals development and joint performance improvement for $\mathrm{C} / \mathrm{C}$ composite brazing.

Keywords: Carbon-carbon composite, Common brazing filler metals, Active brazing filler metal, Surface treatment of $\mathrm{C} / \mathrm{C}$ composites, Composite brazing filler metal

\footnotetext{
*Corresponding Author: Weimin Long: Department of Mechanical Engineering, Tsinghua University, Haidian District, Beijing, 100084, China; State Key Laboratory of Advanced Brazing Filler Metals \& Technology, Zhengzhou Research Institute of Mechanical Engineering Co., LTD, No.149 Kexue Avenue, Hi-tech Industries Development Zone, Zhengzhou, 450001, China; Email: longwm17@mails.tsinghua.edu.cn

Shengnan Li: Department of Mechanical Engineering, Tsinghua University, Haidian District, Beijing, 100084, China; State Key Laboratory of Advanced Brazing Filler Metals \& Technology, Zhengzhou Research Institute of Mechanical Engineering Co., LTD, No.149
}

\section{Introduction}

Carbon fiber reinforced carbon matrix composite, also known as carbon/carbon composite (C/C composite) is a new composite material with both functional and structural properties. It is characterized by low density, high specific strength, high specific stiffness, high specific modulus, good thermal conductivity, good fracture toughness, good ablation resistance, good thermal shock resistance, excellent friction and wear resistance, good fatigue resistance and corrosion resistance, etc. [1, 2]. It is widely used in aerospace, navigation, nuclear energy, medical, military project and other high-tech fields [3]. C/C composite has been developed rapidly since its appearance, and with the rapid development of low-cost rapid preparation technology and high-temperature oxidation resistance technology, more and more attention will be paid to $\mathrm{C} / \mathrm{C}$ composites.

While expanding its application fields, the individual use of $\mathrm{C} / \mathrm{C}$ composite is limited to a certain extent. It is difficult and expensive to directly prepare large and complex components because of the complex preparation process and long generation cycle of $\mathrm{C} / \mathrm{C}$ composites. Meanwhile, the plasticity, deformation and workability of $\mathrm{C} / \mathrm{C}$ composite are poor. Generally, in order to reduce costs and improve production efficiency, the economical and feasible solution is to join $\mathrm{C} / \mathrm{C}$ composites to metals or other materials without affecting the structural performance, while giving

Kexue Avenue, Hi-tech Industries Development Zone, Zhengzhou, 450001, China

Dong Du: Department of Mechanical Engineering, Tsinghua University, Haidian District, Beijing, 100084, China

Lei Zhang: State Key Laboratory of Advanced Brazing Filler Metals \& Technology, Zhengzhou Research Institute of Mechanical Engineering Co., LTD, No.149 Kexue Avenue, Hi-tech Industries Development Zone, Zhengzhou, 450001, China

Xiaoguo Song: State Key Laboratory of Advanced Welding and Joining, Harbin Institute of Technology, Harbin 150001, China Yongguang Zheng: China Railway Engineering Equipment Group Co., Ltd., Zhengzhou 450016, China

Guoqin Huang: Institute of Manufacturing Engineering, Huaqiao University, Xiamen, 361011, China 
play to their own advantages, so as to meet the processing requirements of special size and shape components.

So far, the joining methods of $\mathrm{C} / \mathrm{C}$ composites include mechanical joining $[4,5]$, adhesive joining $[5,6]$, brazing, diffusion bonding and high-temperature self-propagating reaction, etc. There are some limitations in both mechanical and adhesive joining. $\mathrm{C} / \mathrm{C}$ composite cannot be joined by the conventional fusion welding methods since its high melting point $\left(3600^{\circ} \mathrm{C} 3800^{\circ} \mathrm{C}\right)$. As an economical and reliable method of material joining, brazing is a kind of joining method between $\mathrm{C} / \mathrm{C}$ composites and metals that has been studied most, maturest and most widely used in recent decades.

In the brazing process of $\mathrm{C} / \mathrm{C}$ composite, the melted brazing filler metal can not only wet the matrix, but also disperse the joint pressure evenly at the interface. The thermal stress concentration phenomenon caused by the mismatch of the thermal expansion coefficient was alleviated. Meanwhile, the brazed parts are joined through the molten brazing filler metals. The properties of the braze joints are determined by the properties of the brazing filler metals and the interaction between them and base materials to a great extent. C/C composite should be well wetted by the brazing filler metals. Moreover, the properties of brazing joints are also related to the composition of joint products, the structure of compounds, the structure of matrix material interface, and difference of thermal expansion coefficient of brazed parts. Therefore, the quality of brazed joint is largely determined by the brazing filler metal. It is significant to choose filler materials reasonably for improving the reliability of the joint. At present, there is no brazing filler alloy exclusively recommended for commercial C/C composites and metal brazing [7]. Many experts and scholars have studied the joining of $\mathrm{C} / \mathrm{C}$ composites with different filler metals. The summarization of the overview on the application of brazing filler metals is made in this paper. The basic reference basis is provided for the subsequent brazing filler metals development and joint performance improvement for $\mathrm{C} / \mathrm{C}$ composite brazing.

\section{Common brazing filler metals}

\subsection{Al-based brazing filler metals}

When brazing $\mathrm{C} / \mathrm{C}$ composite, it requires not only the wetting ability of brazing filler metal on the workpiece but also the chemical reaction between filler and $\mathrm{C} / \mathrm{C}$ composite to form high strength metallurgical bonding [8]. Currently, the commonly used filler metals include Al-based, Ag-based, Cu-Ni-based brazing filler metals, etc.

Aluminum and aluminum alloys occupy a unique position in modern industrial materials due to their low density, high thermal conductivity and electrical conductivity. Albased brazing filler metal is characterized by low cost, low melting point and low operating temperature. When applying in brazing of $\mathrm{C} / \mathrm{C}$ composite, $\mathrm{Al}$ from the brazing filler metal can react with $\mathrm{C}$ from $\mathrm{C} / \mathrm{C}$ composite to generate $\mathrm{Al}_{4} \mathrm{C}_{3}$ compound, so as to realize high strength joining of $\mathrm{C} / \mathrm{C}$ composite. However, the existence of $\mathrm{Al}$ elementary substance in the joint makes it unsuitable to be used at high temperature. The applications of Al-based brazing filler metals in joining of $\mathrm{C} / \mathrm{C}$ composites are shown in Table 1 .

Although $\mathrm{Al}$ and $\mathrm{C}$ can react to form $\mathrm{Al}_{4} \mathrm{C}_{3}$ compound, $\mathrm{Al}$ can wet carbon materials only at high temperature. Therefore, it is generally preferred to add active element $\mathrm{Ti}$ to increase the wettability of the brazing filler metal on $\mathrm{C} / \mathrm{C}$ composites' surface. On the other hand, Ti can react with $\mathrm{C}$ to form TiC intermetallic compounds, further improving the bonding strength. However, the addition amount of $\mathrm{Ti}$ should not be too much to avoid the brittle TiC layer is too thick, which will affect the interface joining strength.

\subsection{Ag-based brazing filler metals}

Ag-based brazing filler metal has the advantages of moderate melting point, good manufacturability, good strength, good toughness, high electrical conductivity, high thermal conductivity and good corrosion resistance. It is a kind of widely used brazing filler metal. The main alloying ele-

Table 1: Al-based brazing filler metals used in joining of $\mathrm{C} / \mathrm{C}$ composites

\begin{tabular}{ccccc}
\hline $\begin{array}{c}\text { Composition of brazing filler } \\
\text { metal (wt. \%) }\end{array}$ & $\begin{array}{c}\text { Base } \\
\text { materials }\end{array}$ & $\begin{array}{c}\text { Brazing temperature }\left({ }^{\circ} \mathrm{C}\right) \\
\text { Holding time (min) }\end{array}$ & $\begin{array}{c}\text { Strength } \\
(\mathrm{MPa})\end{array}$ & $\begin{array}{c}\text { References } \\
{[9]}\end{array}$ \\
\hline $\mathrm{Al}$ & $\mathrm{C} / \mathrm{C}-\mathrm{C} / \mathrm{C}$ & $1000 / 45$ & $10($ Shear) \\
$\mathrm{Al-Ti}$ & $\mathrm{C} / \mathrm{C}-\mathrm{C} / \mathrm{C}$ & $1110 / 10$ & $12.3($ Shear) & {$[10]$} \\
$\mathrm{Al}-15 \mathrm{Ti}$ & $\mathrm{C} / \mathrm{C}-\mathrm{C} / \mathrm{C}$ & $1100 / 10$ & $16($ Shear) & {$[11]$} \\
$\mathrm{Al}-14 \mathrm{Ti}$ & $\mathrm{C} / \mathrm{C}-\mathrm{C} / \mathrm{C}$ & $1050 / 10$ & 14.7 (Tensile) & {$[12]$} \\
\hline
\end{tabular}


Table 2: Ag-based brazing filler metals used in joining of $\mathrm{C} / \mathrm{C}$ composites

\begin{tabular}{|c|c|c|c|c|}
\hline $\begin{array}{c}\text { Composition of brazing filler } \\
\text { metal (wt. \%) }\end{array}$ & Base materials & $\begin{array}{c}\text { Brazing temperature }\left({ }^{\circ} \mathrm{C}\right) \\
\text { Holding time (min) }\end{array}$ & Strength (MPa) & References \\
\hline $\mathrm{Ag} 28 \mathrm{Cu}$ & C/C-TC4 & $850 / 10$ & 38 (Shear) & [16] \\
\hline $\mathrm{Ag} 28 \mathrm{Cu}$ & C/C-TC4 & $880 / 10$ & 33 (Shear) & [17] \\
\hline $\mathrm{Ag}-\mathrm{Cu}-2 \mathrm{Ti}$ & $\mathrm{C} / \mathrm{C}-\mathrm{CuCr}$ & $850 / 5$ & 16 (Shear) & [18] \\
\hline $\mathrm{Ag}-\mathrm{Cu}-2 \mathrm{Ti}$ & C/C-CuW & $850 / 5$ & 13 (Shear) & [18] \\
\hline $\mathrm{Ag}-26.4 \mathrm{Cu}-4.6 \mathrm{Ti}$ & $\mathrm{C} / \mathrm{C}-\mathrm{C} / \mathrm{C}$ & $900 / 10$ & $\begin{array}{c}22 \text { (Shear) } \\
38 \text { (Bending) }\end{array}$ & [19] \\
\hline $68.8 \mathrm{Ag}-26.7 \mathrm{Cu}-4.5 \mathrm{Ti}$ & $\mathrm{C} / \mathrm{C}-\mathrm{Ti}$ & $910 / 5$ & $\begin{array}{c}0.24 \pm 0.09 \\
\text { (Tensile) }\end{array}$ & [20-22] \\
\hline $\mathrm{Ag}-26.7 \mathrm{Cu}-4.6 \mathrm{Ti}$ & $\mathrm{C} / \mathrm{C}-\mathrm{TC} 4$ & $910 / 10$ & 25 (Shear) & {$[23-25]$} \\
\hline $68.8 \mathrm{Ag}-26.7 \mathrm{Cu}-4.5 \mathrm{Ti}$ & $\mathrm{C} / \mathrm{C}-(\mathrm{Cu}-\mathrm{Mo}-\mathrm{Cu})$ & $(915 \sim 920) / 5$ & - & {$[26,27]$} \\
\hline $63 \mathrm{Ag}-34.3 \mathrm{Cu}-1 \mathrm{Sn}-1.75 \mathrm{Ti}$ & $\mathrm{C} / \mathrm{C}-(\mathrm{Cu}-\mathrm{Mo}-\mathrm{Cu})$ & $(821 \sim 826) / 5$ & - & [26] \\
\hline $63 \mathrm{Ag}-35.3 \mathrm{Cu}-1.75 \mathrm{Ti}$ & $\mathrm{C} / \mathrm{C}-(\mathrm{Cu}-\mathrm{Mo}-\mathrm{Cu})$ & $(830 \sim 835) / 5$ & - & [27] \\
\hline $63 \mathrm{Ag}-32.25 \mathrm{Cu}-1.75 \mathrm{Ti}$ & $\begin{array}{l}\text { C/C-Graphite } \\
\text { foam-Ti tube }\end{array}$ & $820 / 5$ & $\begin{array}{c}12.4 \text { (Shear) } \\
11.8 \text { (Tensile) }\end{array}$ & [28] \\
\hline $\mathrm{Ag}-26.7 \mathrm{Cu}-4.6 \mathrm{Ti}$ & C/C-TiAl & $900 / 10$ & 12.9 (Shear) & [29] \\
\hline $\mathrm{Ag} 26 \mathrm{Cu} 2 \mathrm{Ti}$ & $\begin{array}{l}\text { C/C-K24 } \\
\text { (Ni-based) }\end{array}$ & $880 / 10$ & 16 (Shear) & [30] \\
\hline $\mathrm{Ag}-32.25 \mathrm{Cu}-1.75 \mathrm{Ti}$ & C/C-Pure Ti & $830 / 5$ & 24 (Shear) & [31] \\
\hline $70 \mathrm{Ag} 28 \mathrm{Cu} 2 \mathrm{Ti}$ & C/C-TC4 & $860 / 10$ & 28 (Shear) & [32] \\
\hline $\mathrm{Ag}-27 \mathrm{Cu}-3.5 \mathrm{Ti}$ & $\mathrm{C} / \mathrm{C}-\mathrm{C} / \mathrm{C}$ & $900 / 10$ & 20 (Shear) & [33] \\
\hline $\mathrm{Ag}-26.7 \mathrm{Cu}-4.6 \mathrm{Ti}$ & C/C-TC4 & $900 / 10$ & - & [34] \\
\hline $\mathrm{Ag}-26.7 \mathrm{Cu}-4.5 \mathrm{Ti}$ & $\mathrm{C} / \mathrm{C}-\mathrm{C} / \mathrm{C}$ & $850 / 30$ & 26.7 (Shear) & [35] \\
\hline $\mathrm{Ag} 27 \mathrm{Cu} 3 \mathrm{Ti}$ & C/C-Rene N5 & $910 / 10$ & $\begin{array}{l}\text { Shear: } 18.7 \\
\text { (Flat), } 31 \\
\text { (zigzag } \\
\text { grooved) }\end{array}$ & [36] \\
\hline $68.83 \mathrm{Ag}-26.77 \mathrm{Cu}-4.4 \mathrm{Ti}$ & C/C-TC17 & $860 / 15$ & $24 \pm 1$ (Shear) & [14] \\
\hline $\mathrm{Ag}-68.8 \mathrm{Cu}-4.5 \mathrm{Ti}$ & $\mathrm{C} / \mathrm{C}-\mathrm{Cu}$ & $910 / 10$ & $\begin{array}{l}\text { Bending: } 14 \\
\text { (Flat), } 52 \\
\text { (Conical } \\
\text { interface) }\end{array}$ & [37] \\
\hline $\mathrm{Cu}-28 \mathrm{Ag}-2 \mathrm{Ti}$ & $\mathrm{C} / \mathrm{C}-\mathrm{OF} \mathrm{Cu}$ & $850 / 10$ & 22 (Shear) & [38] \\
\hline$A g-(10,20,30,40) \mathrm{Ti}$ & C/C-GH3044 & $(990 \sim 1080) /(10 \sim 90)$ & $\begin{array}{l}45.8 \text { (Shear) } \\
\text { (Ag-20Ti; } \\
1020 / 30)\end{array}$ & [39] \\
\hline
\end{tabular}

ments of Ag-based brazing filler metal include $\mathrm{Cu}, \mathrm{Zn}, \mathrm{Cd}$ and $\mathrm{Sn}$, etc. Since the addition of $\mathrm{Cu}$ can reduce the melting temperature of silver without forming brittle phases, $\mathrm{Cu}$ is the most important alloying element. Brazing filler metals with Ag-Cu alloy as the matrix, assisted adding $\mathrm{Zn}$, In, $\mathrm{Mn}, \mathrm{Ni}, \mathrm{Si}, \mathrm{Sn}, \mathrm{Ti}$ and other metal elements possess the advantages of good brazing temperature controllability [13], good wettability with the joined parts, and strong filling gap ability, and so on. Compared with Ni-based or Ti based brazing filler metal, the brazing temperature of Ag-based brazing filler metal is lower. The applications of Ag-based brazing filler metals in joining of $\mathrm{C} / \mathrm{C}$ composites are shown in Table 2.

It can be seen from Table 2 that the Ag-based brazing filler metals used for brazing $\mathrm{C} / \mathrm{C}$ composites are mainly $\mathrm{Ag}$-Cu eutectic alloy and Ag-Cu-Ti brazing filler metals. Ag$\mathrm{Cu}$-Ti brazing filler metal is one kind of relatively mature and most important active brazing filler metals in the active brazing method. Its low melting temperature makes it is suitable for medium and low temperature. Ag-Cu-Ti used in 

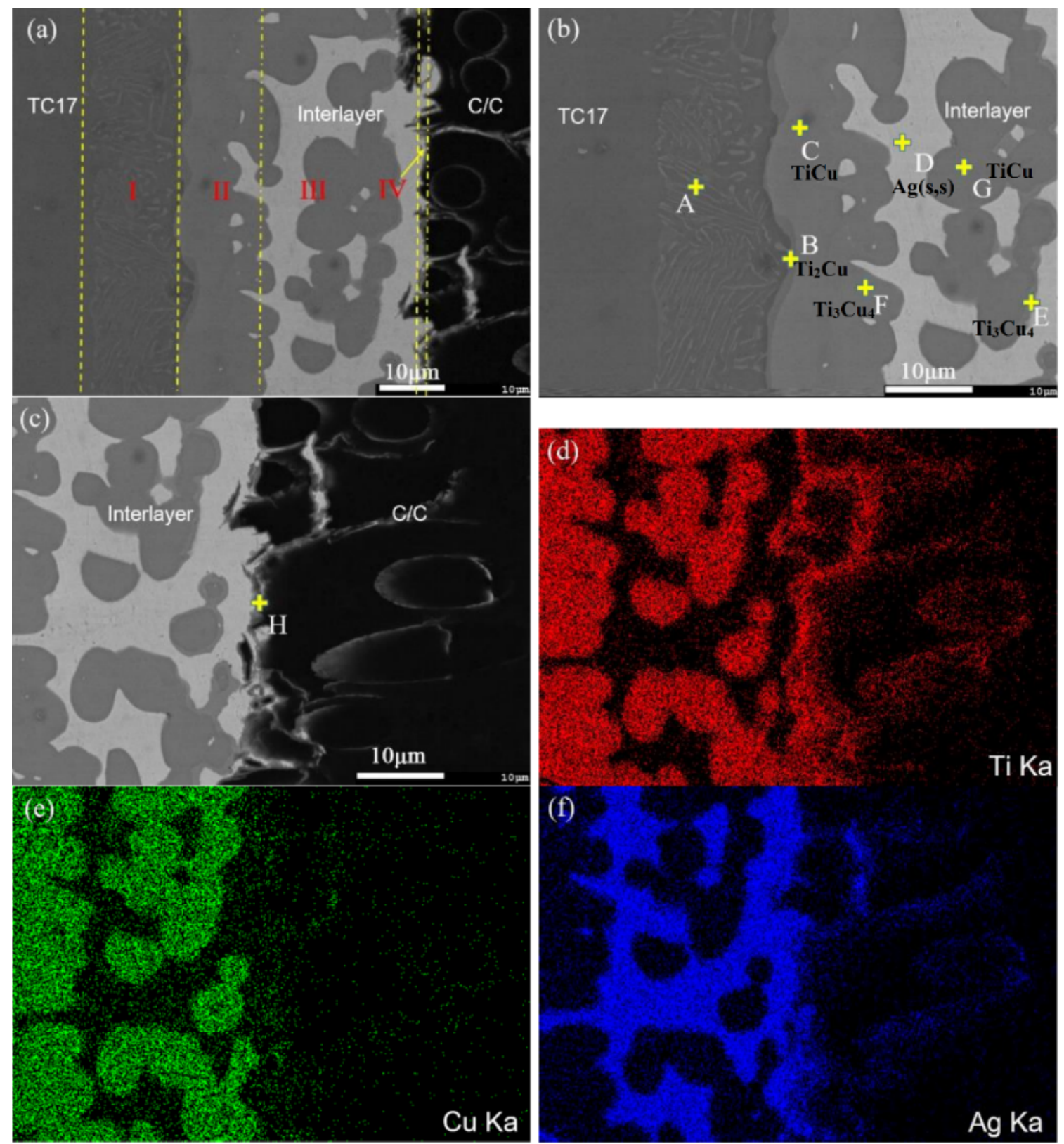

Figure 1: Back-scattered electron image of C/C composite/ AgCuTi/ TC17 joint.

brazing $\mathrm{C} / \mathrm{C}$ composites is generally based on $\mathrm{Ag}-\mathrm{Cu}$ eutectic and added trace Ti element. The content of Ti ranges from 1.75 wt.\% to 4.6 wt.\%. During brazing process, interfacial metallurgical bonding was formed thanks to the elements diffusion and chemical reaction (Figure 1) [14]. The content of element $\mathrm{Ti}$ and $\mathrm{Cu}$ indicates that diffusion and reactions occur between base material and brazing filler. According the thermodynamic data [15], the Gibbs free energy of TiC formation are represented as follows:

$$
\mathrm{Ti}+\mathrm{C} \rightarrow \mathrm{TiC} \quad \Delta G^{0}=-183.1+0.01 \mathrm{~T}(\mathrm{~kJ} / \mathrm{mol})
$$

The Gibbs free energy of forming TiC calculated by Equation (1) is about $-172.2 \mathrm{~kJ} / \mathrm{mol} \sim-171.2 \mathrm{~kJ} / \mathrm{mol}$ at $820^{\circ} \mathrm{C} \sim 920^{\circ} \mathrm{C}$. Therefore, element Ti and $\mathrm{C}$ can react with each other while using $\mathrm{Ag}$-Cu-Ti fillers to brazing $\mathrm{C} / \mathrm{C}$ composite.

Ag-based brazing filler metals are commonly used for brazes between $\mathrm{C} / \mathrm{C}$ composites and Ti alloys, $\mathrm{Cu}$ alloys and Ni-based superalloys. The strength of brazing joint varies with different material composition and structure. Most of the shear strength of the joints was above $20 \mathrm{MPa}$, which was close to the interlaminar shear strength of $\mathrm{C} / \mathrm{C}$ composites. 


\subsection{Cu-based brazing filler metals}

Cu-based brazing filler metal has the characteristics of relatively high high-temperature bearing capacity, good strength, good plasticity and relatively low price. Researches showed that $\mathrm{Cu}$-based brazing filler metals were widely used in brazing of $\mathrm{C} / \mathrm{C}$ composites, carbon-based ceramic composites and metals. Some scholars pointed out that $\mathrm{C} / \mathrm{C}$ composite does not bond well with pure $\mathrm{Cu}$ since

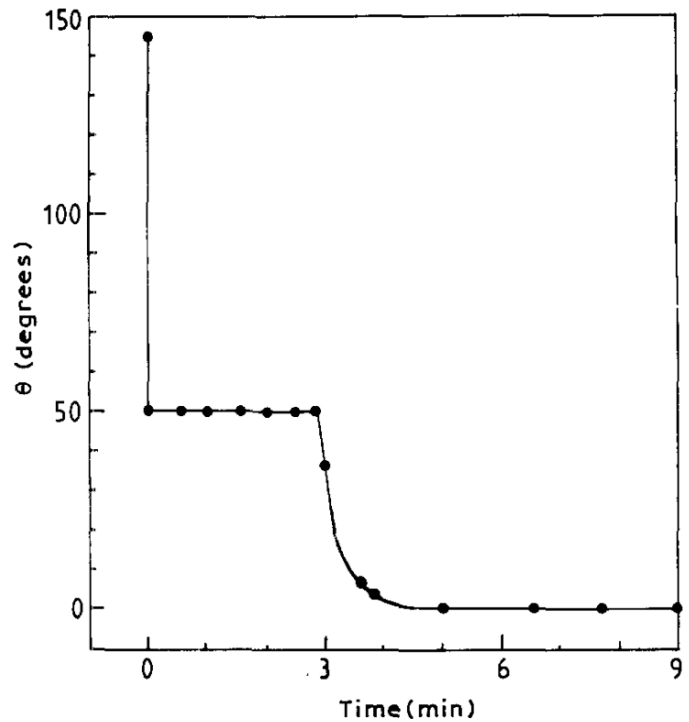

Figure 2: Contact angle, $\theta$, of the (Cu-12.6 at\% Ti) alloy on the glassy carbon substrate as a function of time at $1350 \mathrm{~K}$. the wetting angle of molten copper on carbon substrates is very high, approximately $137^{\circ} \sim 140^{\circ}[40,41]$. However, the surface wetting on $\mathrm{C} / \mathrm{C}$ composites was greatly improved by $\mathrm{Cu}$ after the addition of Ti element. Li proved that the wetting angle of $\mathrm{Cu}-12.6 \mathrm{Ti}$ (at. \%) on carbon materials was close to $0^{\circ}$ under the condition of $1077^{\circ} \mathrm{C}$ heat preservation $5 \mathrm{~min}$ [42]. The reason is that after adding Ti element into $\mathrm{Cu}$-based brazing filler metal, $\mathrm{Ti}$ and $\mathrm{C}$ will react to generate $\mathrm{TiC}$, improving the wettability of the brazing filler metal on base materials (Figure 2). Between the instantaneous process of the pure copper on the same substrate (Figure 3) to $50^{\circ}$ and the process of the reduction in $\theta$ from $50^{\circ}$ to the stationary value of zero, which proceeds quite quickly, there is an intermediate plateau of $\theta$ at a value

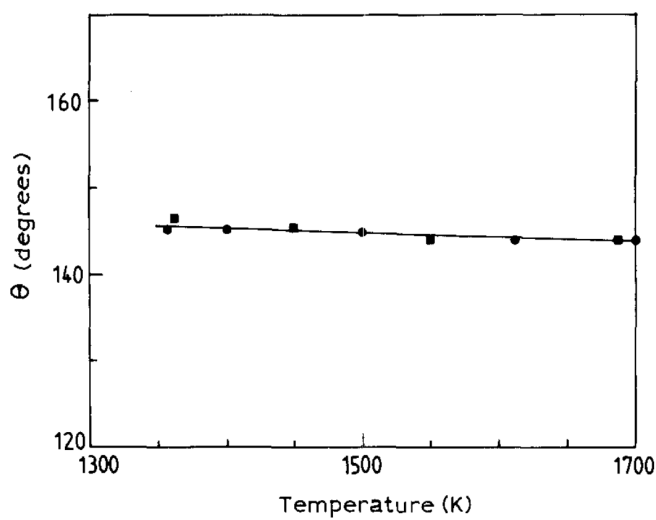

Figure 3: Contact angle, $\theta$, of pure copper on glassy carbon versus temperature.

Table 3: $\mathrm{Cu}$-based brazing filler metals used in joining of $\mathrm{C} / \mathrm{C}$ composites

\begin{tabular}{|c|c|c|c|c|}
\hline $\begin{array}{c}\text { Composition of brazing filler } \\
\text { metal (wt. \%) }\end{array}$ & Base materials & $\begin{array}{l}\text { Brazing temperature }\left({ }^{\circ} \mathrm{C}\right) \\
\text { Holding time (min) }\end{array}$ & Strength (MPa) & References \\
\hline Cu-30Ti & $\mathrm{C} / \mathrm{C}-\mathrm{Cu}$ & 930 & 7 (Shear) & [18] \\
\hline Cu15Ti & $\mathrm{C} / \mathrm{C}-\mathrm{C} / \mathrm{C}$ & $1050 / 30$ & 21 (Shear) & {$[43,45]$} \\
\hline Cu-14Ti & $\mathrm{C} / \mathrm{C}-\mathrm{C} / \mathrm{C}$ & $1200 / 10$ & - & [44] \\
\hline Cu-Ti (TLP-DB) $(0.4,0.6,0.8$, & $\mathrm{C} / \mathrm{C}-\mathrm{Nb}$ & $1050 / 30$ & 28.6 (Shear) & [46] \\
\hline $0.9,1.0,1.1) \mathrm{mm} \mathrm{Cu}$ & & & $0.9 \mathrm{mmCu}$ & \\
\hline$+0.1 \mathrm{mmTi}$ & & & $+0.1 \mathrm{mmTi}$ & \\
\hline $\mathrm{Cu}-50 \mathrm{~Pb}$ & $\mathrm{C} / \mathrm{C}-\mathrm{Cu}$ & $1150 / 40$ & 1.5 (Shear) & [47] \\
\hline $99 \mathrm{Cu}-1 \mathrm{Cr}$ & $C / C-W$ & $1155 / 5$ & 24.7 (Shear) & [48] \\
\hline $\mathrm{Cu}-(15 \sim 25) \mathrm{Mn}-(8 \sim 14) \mathrm{Ti}$ & $\begin{array}{l}\text { C/C-Stainless } \\
\text { steel }\end{array}$ & $(850 \sim 950) /(2 \sim 10)$ & 16 (Shear) & {$[49,50]$} \\
\hline $\mathrm{Cu}-2 \mathrm{Al}-3 \mathrm{Si}-2.3 \mathrm{Ti}$ & $\mathrm{C} / \mathrm{C}-\mathrm{OF} \mathrm{Cu}$ & $1030 \pm 2$ & 20.2 (Tensile) & [51] \\
\hline $92.8 \mathrm{Cu}-3 \mathrm{Si}-2 \mathrm{Al}-2.2 \mathrm{Ti}$ & $\mathrm{C} / \mathrm{C}-\mathrm{Ti}$ & $1040 / 5$ & $\begin{array}{c}0.27 \pm 0.12 \\
\text { (Tensile) }\end{array}$ & {$[20-22]$} \\
\hline $92.8 \mathrm{Cu}-3 \mathrm{Si}-2 \mathrm{Al}-2.25 \mathrm{Ti}$ & $\mathrm{C} / \mathrm{C}-(\mathrm{Cu}-\mathrm{Mo}-\mathrm{Cu})$ & $(1040 \sim 1045) / 5$ & - & [26] \\
\hline Cu75Pt25 & $\mathrm{C} / \mathrm{C}-\mathrm{Nb}$ & $1160 / 20$ & $\begin{array}{l}\text { Shear: } 26.7(\mathrm{RT}) \text {, } \\
17.6\left(600^{\circ} \mathrm{C}\right)\end{array}$ & [52] \\
\hline
\end{tabular}


of $50^{\circ}$ for about $3 \mathrm{~min}$, indicating the existence of an incubation period needed to initiate the chemical reactions between the absorbed titanium and carbon. The kinetics and mechanism of chemical reactions developing at interfaces are important because the reactive wetting process depends on represents the first important step towards the understanding of the reactive wetting phenomena.

The applications of $\mathrm{Cu}$-based brazing filler metals in joining of $\mathrm{C} / \mathrm{C}$ composites are shown in Table 3.

Since $\mathrm{C}$ and $\mathrm{Cu}$ can react to form solid solution, a diffusion layer with gradual composition will be formed when $\mathrm{Cu}$ diffuses to $\mathrm{C} / \mathrm{C}$ composite and $\mathrm{C}$ diffuses to the brazing joint. The diffusion layer has better compatibility with $\mathrm{C} / \mathrm{C}$ composite than that of the brazing filler metal with $\mathrm{C} / \mathrm{C} \mathrm{com}$ posite [43]. Adding Ti in copper matrix, Ti elements will be enriched towards the interface and form $\mathrm{TiC}$ because of the action of chemical and physical adsorption, during which the interfacial tension decreases. Therefore, the wettability of $\mathrm{Cu}$-based brazing filler metal on $\mathrm{C} / \mathrm{C}$ composite will be improved by adding Ti elements. The brazing filler alloys also can penetrate into the pores of $\mathrm{C} / \mathrm{C}$ composite by capillary force to form a strong interface bonding [44].

\subsection{Ti-based brazing filler metals}

The corrosion resistance and high temperature strength of Ti-based brazing filler metals are superior compared with Al-based or Ag-based brazing filler metals. The Ti-based brazing filler metals used for brazing carbon materials are mainly binary or ternary alloys of Ti. Although pure Ti can also be used for brazing carbon materials, a very thick carbide layer will be generated at the joint due to the strong (a)

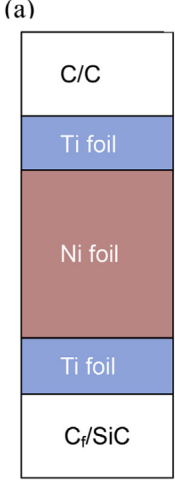
(b)

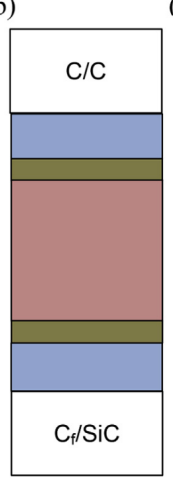

(c)

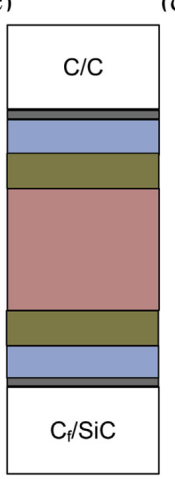

(d)

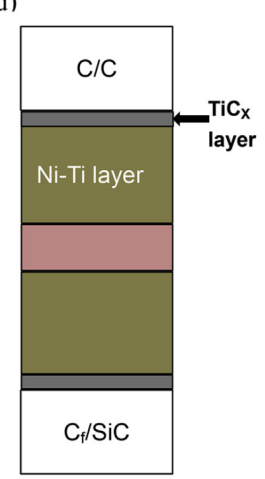

Figure 4: The formation model of the $\mathrm{C} / \mathrm{C}-\mathrm{C}_{f} / \mathrm{SiC}$ composite joint.

Table 4: Ti-based brazing filler metals used in joining of $C / C$ composites

\begin{tabular}{|c|c|c|c|c|}
\hline $\begin{array}{c}\text { Composition of brazing filler } \\
\text { metal (wt. \%) }\end{array}$ & Base materials & $\begin{array}{c}\text { Brazing temperature }\left({ }^{\circ} \mathrm{C}\right) \\
\text { Holding time }(\mathrm{min})\end{array}$ & Strength (MPa) & References \\
\hline 49Ti-49Cu-2Be & $\begin{array}{l}\text { C/C-Metals (Cu, } \\
\text { steel, etc.) }\end{array}$ & $980 / 5$ & - & [53] \\
\hline $\begin{array}{l}\text { Ti-Ni-Si } \\
(1: 1: 4) \text { PTLP }\end{array}$ & $\mathrm{C} / \mathrm{C}-\mathrm{C} / \mathrm{C}$ & $1150 / 4530 \mathrm{MPa}$ & 23.58 (Shear) & [54] \\
\hline $\begin{array}{c}\text { Ti-SiC-Si-C } \\
(3: 1: 1: 1) \text { vacuum hot } \\
\text { pressing }\end{array}$ & $\mathrm{C} / \mathrm{C}-\mathrm{C} / \mathrm{C}$ & $1600 / 630 \mathrm{MPa}$ & $\begin{array}{l}38.09 \pm 5.09 \\
\text { (Shear) }\end{array}$ & [55] \\
\hline 70Ti15Cu15Ni & $\mathrm{C} / \mathrm{C}-\mathrm{Cu}$ & $1000 / 10$ & 24 (Shear) & {$[56,57]$} \\
\hline $70 \mathrm{Ti} 15 \mathrm{Cu} 15 \mathrm{Ni}$ & C/C-(Cu-Mo-Cu) & $975-980 / 5$ & - & [26] \\
\hline 70Ti15Cu15Ni & $\mathrm{C} / \mathrm{C}-\mathrm{Ti}$ & $975 / 5$ & $\begin{array}{c}0.33 \pm 0.13 \\
\text { (Tensile) }\end{array}$ & {$[20-22]$} \\
\hline Ti35Zr10Ni15Cu & C/C-(TiBw-TC4) & $900 / 10$ & 13.6 (Shear) & [58] \\
\hline $50 \mathrm{Ti} 50 \mathrm{Ni}$ & $\begin{array}{l}\text { (low density) } \\
\mathrm{C} / \mathrm{C}-\mathrm{Nb}\end{array}$ & $1200 / 20$ & $\begin{array}{c}\text { Shear: } 44(\mathrm{RT}), 36 \\
\left(600^{\circ} \mathrm{C}\right)\end{array}$ & [59] \\
\hline $50 \mathrm{Ti} 50 \mathrm{Ni}$ & $\begin{array}{l}\text { (high density) } \\
\quad \mathrm{C} / \mathrm{C}-\mathrm{Nb}\end{array}$ & $1200 / 20$ & $\begin{array}{c}\text { Shear: } 17 \text { (Flat), } \\
92 \text { (Conical } \\
\text { interface) }\end{array}$ & [59] \\
\hline Ti-Ni-Cu (1:1:1) & C/C-TiAl & $980 / 10$ & 18 (Shear) & [60] \\
\hline $\mathrm{TiSi}_{2}$ & $\mathrm{C} / \mathrm{C}-\mathrm{C} / \mathrm{C}$ & $1490 / 2$ & $\begin{array}{l}\text { Shear: } 34.4 \pm 9.6 \\
\left(1164^{\circ} \mathrm{C}\right)\end{array}$ & [61] \\
\hline Ti-Ni-Ti $(1: 3: 1)$ & $\mathrm{C} / \mathrm{C}-\mathrm{C}_{f} / \mathrm{SiC}$ & $960 / 300.5 \mathrm{MPa}$ & $\begin{array}{c}44.7 \pm \\
12.8(\text { Shear) }\end{array}$ & [62] \\
\hline
\end{tabular}


reaction between $\mathrm{Ti}$ and $\mathrm{C}$. Moreover, the coefficient of thermal expansion of pure $\mathrm{Ti}$ is high, which is easy to cause cracks in carbon materials. Adding a small amount of $\mathrm{Cr}$ and Ni to Ti matrix can reduce the melting point of Ti-based brazing filler metal and improve its wettability (Figure 4). In addition, 49Ti-49Cu-2Be [53], Ti-Ni-Si [54] and Ti-Si-SiC-C [55] can be used for brazing $\mathrm{C} / \mathrm{C}$ composites as well. The applications of Ti-based brazing filler metals in joining of $\mathrm{C} / \mathrm{C}$ composites are shown in Table 4.

\subsection{Ni-based brazing filler metals}

At present, when joining C/C composites, Ag-based or $\mathrm{Cu}$ based brazing filler metals are widely used. However, the service temperature of Ag-based or Cu-based brazing filler metals is lower, which cannot guarantee reliable joining strength while above $500^{\circ} \mathrm{C}$. It is unable to reflect the excellent high-temperature performance of $\mathrm{C} / \mathrm{C}$ composite. For example, the joint using Ag-based or Cu-based brazing filler metal cannot meet the high temperature service requirements when $\mathrm{C} / \mathrm{C}$ composite is used in the engine nozzle. Therefore, it is necessary to search and develop brazing filler metals which meet the requirements of high temperature performance.
Ni-based brazing filler metal is used for brazing workpiece that works at high temperature. It has excellent corrosion resistance and heat resistance. The bearable servicing temperature of the brazing joints using Ni-based brazing filler metals can reach up to $1000^{\circ} \mathrm{C}$. The brazing joints using Ni-based brazing filler metals also have satisfactory performance in liquid oxygen, liquid nitrogen and other low temperature media. Whereas, the melting point of nickel

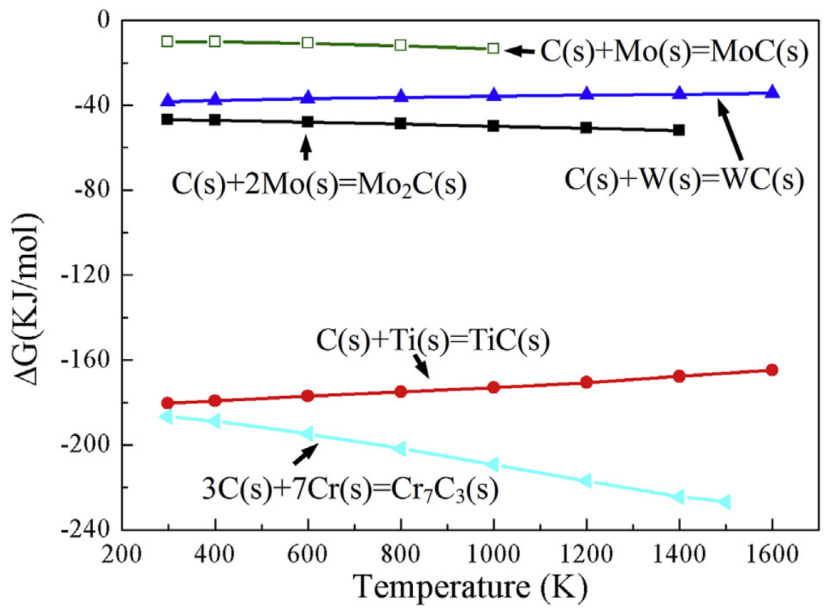

Figure 5: Gibbs free energy calculation results of carbides.

Table 5: Ni-based brazing filler metals used in joining of $C / C$ composites

\begin{tabular}{|c|c|c|c|c|}
\hline $\begin{array}{c}\text { Composition of brazing filler } \\
\text { metal (wt. \%) }\end{array}$ & Base materials & $\begin{array}{l}\text { Brazing temperature }\left({ }^{\circ} \mathrm{C}\right) \\
\text { Holding time (min) }\end{array}$ & Strength (MPa) & References \\
\hline $\mathrm{Ni}-33 \mathrm{Cr}-24 \mathrm{Pd}-4 \mathrm{Si}$ & $\mathrm{C} / \mathrm{C}-\mathrm{Cu}$ & 1210 & 6 (Shear) & [18] \\
\hline $\mathrm{Ni}-11 \mathrm{Cr}-10 \mathrm{P}$ & $\mathrm{C} / \mathrm{C}-\mathrm{Cu}$ & 935 & 7 (Shear) & [18] \\
\hline $\mathrm{Ni}-\mathrm{Zr}-\mathrm{Cr}$ & $\mathrm{C} / \mathrm{C}-\mathrm{C} / \mathrm{C}$ & $1270 / 10$ & 10 (Bending) & [63] \\
\hline $\begin{array}{c}\text { MBF-20 Amorphous } \\
\text { (Ni-6.48Cr-3.13Fe- } \\
\text { 4.38Si-3.13B) }\end{array}$ & $\mathrm{C} / \mathrm{C}-\mathrm{Ti}$ & $1045 / 4$ & - & [64] \\
\hline $\begin{array}{c}\text { MBF-30 Amorphous } \\
\text { (Ni-4.61Si-2.8B-0.02Fe) }\end{array}$ & $\mathrm{C} / \mathrm{C}-\mathrm{Ti}$ & $1080 / 4$ & - & [64] \\
\hline $\begin{array}{c}\mathrm{BNi}-2 \\
\mathrm{Ni}-(6 \sim 8) \mathrm{Cr}-(2.5 \sim 3.5) \mathrm{Fe}- \\
(4 \sim 5) \mathrm{Si}-(2.75 \sim 3.5) \mathrm{B}\end{array}$ & C/C-GH99 & $1170 / 60$ & $\begin{array}{c}\text { Shear: } 35.4(\mathrm{RT}), \\
15.3\left(800^{\circ} \mathrm{C}\right), \\
8.6\left(1000^{\circ} \mathrm{C}\right)\end{array}$ & [65] \\
\hline $\mathrm{Ni}-\mathrm{Si}$ & C/C-GH3128 & 1160 & 12.6 (Shear) & [66] \\
\hline 80Ni-20Ti PTLP & C/C-GH3044 & $1030 / 304.5(\mathrm{MPa})$ & 9.78 (Shear) & [67] \\
\hline $\begin{array}{c}\text { BNi-2 (Ni-7.0Cr- } \\
\text { 3.0Fe-4.5Si-3.1B) }\end{array}$ & C/C-GH3128 & $1170 / 60$ & 24 (Shear) & [68] \\
\hline BNi68CrWB & C/C-GH600 & $1150-1200 / 10$ & $\begin{array}{c}\text { Shear: } 49.9(\mathrm{RT}) \\
21.6\left(800^{\circ} \mathrm{C}\right)\end{array}$ & [69] \\
\hline NiCrSiBFe Amorphous & $\begin{array}{l}\text { C/C-Ni-based } \\
\text { superalloy }\end{array}$ & $1170 / 60$ & $\begin{array}{c}\text { Shear: } 35(\mathrm{RT}), 15 \\
\left(800^{\circ} \mathrm{C}\right), \\
9\left(1000^{\circ} \mathrm{C}\right)\end{array}$ & [70] \\
\hline
\end{tabular}


is high. The thermal strength of nickel is low. The reaction ability of nickel with carbon materials is weak. Alloying elements should be added to reduce its melting point and improve its thermal strength.

$\mathrm{NiP}$ and NiCrP are two kinds of Ni-based brazing filler metals with lowest melting points. They are both able to join materials tightly because of the eutectic structure and excellent fluidity. The main functions of $\mathrm{Cr}$ in $\mathrm{NiCrP}$ are solid solution strengthening by forming solid solution with $\mathrm{Ni}$, and improving the antioxidant capacity of it. $\mathrm{Cr}$ is also used as active element to react with carbon material to form carbide layer. The Gibbs free energy for the formation of $\mathrm{Cr}$-C compound is shown in Figure 5. The applications of Ni-based brazing filler metals in joining of $\mathrm{C} / \mathrm{C}$ composites are shown in Table 5.

It can be seen from Table 5 that Ni-based brazing filler metal is mainly used for the joining between $\mathrm{C} / \mathrm{C}$ composite and Ni-based superalloy. With the development of materials, amorphous active Ni-based brazing filler metals are increasingly used in brazing between $\mathrm{C} / \mathrm{C}$ composites and metals. Through comparison, it is found that the strength of
$\mathrm{C} / \mathrm{C}$ composite joints using Ni-based brazing filler metals is generally lower than that of joints with Ag-based, Cu-based and Ti-based brazing filler metals.

\section{Surface treatment of $\mathrm{C} / \mathrm{C}$ composites before joining}

Indirect brazing is another method that has been used to join $\mathrm{C} / \mathrm{C}$ composites and other materials. Indirect brazing of $\mathrm{C} / \mathrm{C}$ composites usually involves depositing a metal film on the surface or generating a thin carbide layer before brazing (Figure 6). Metals used for surface metallization generally include: $\mathrm{Mo}, \mathrm{W}, \mathrm{Ni}, \mathrm{Cu}, \mathrm{Cr}$, etc. The elements commonly used to generate carbide surface layer are $\mathrm{Cr}$, $\mathrm{Ti}, \mathrm{Mo}$, Ta, etc. In addition, the in-situ synthesis of carbon nanotubes on the $\mathrm{C} / \mathrm{C}$ composite material surface before brazing can also improve the wettability of the filler metal on composite material surface, which is beneficial to the strength of the joint. However, indirect brazing process is complex and
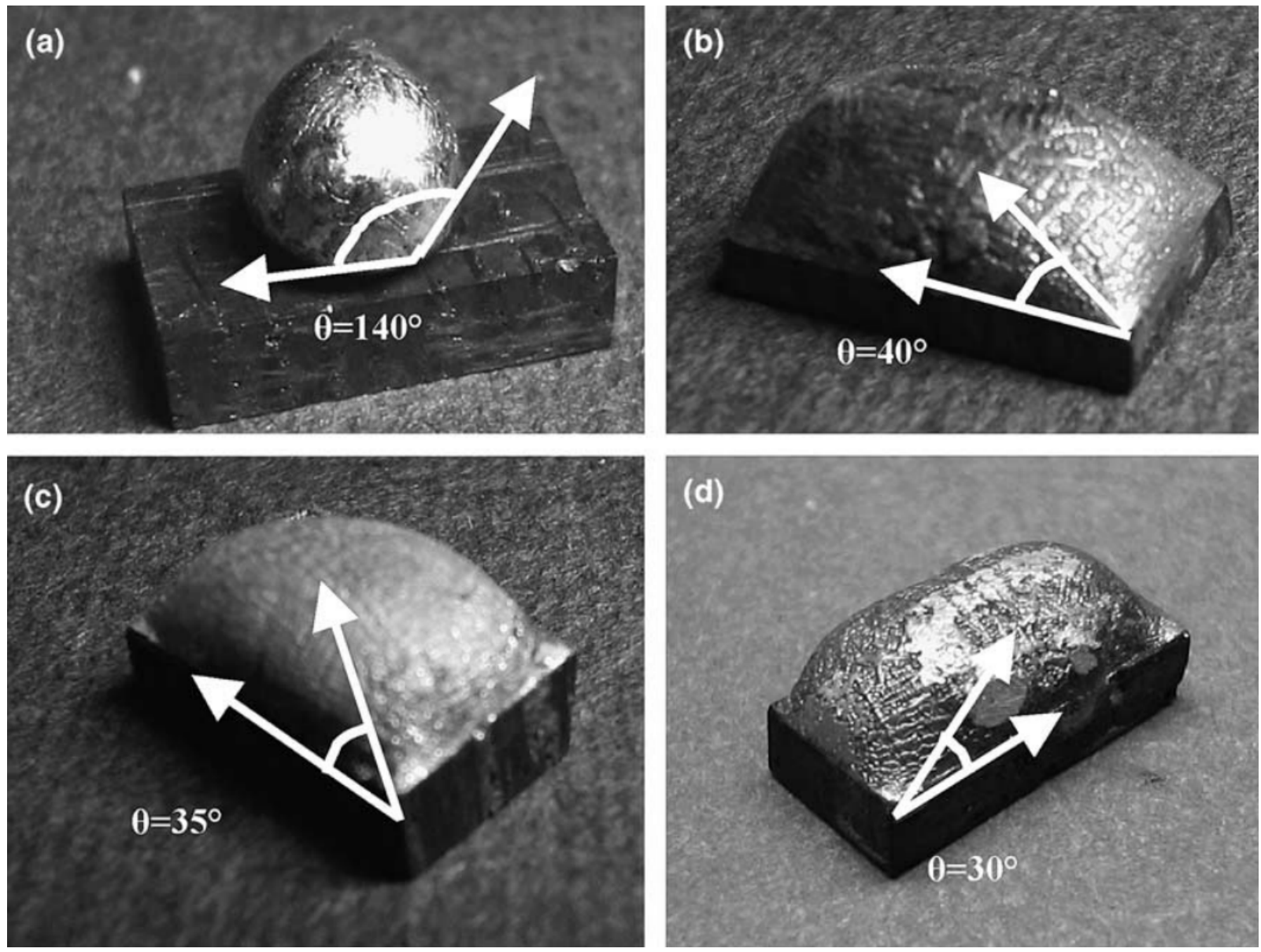

Figure 6: Wettability of pure copper on CFC substrate $\left(1100^{\circ} \mathrm{C}\right.$ for $\left.30 \mathrm{~min}\right)$. 


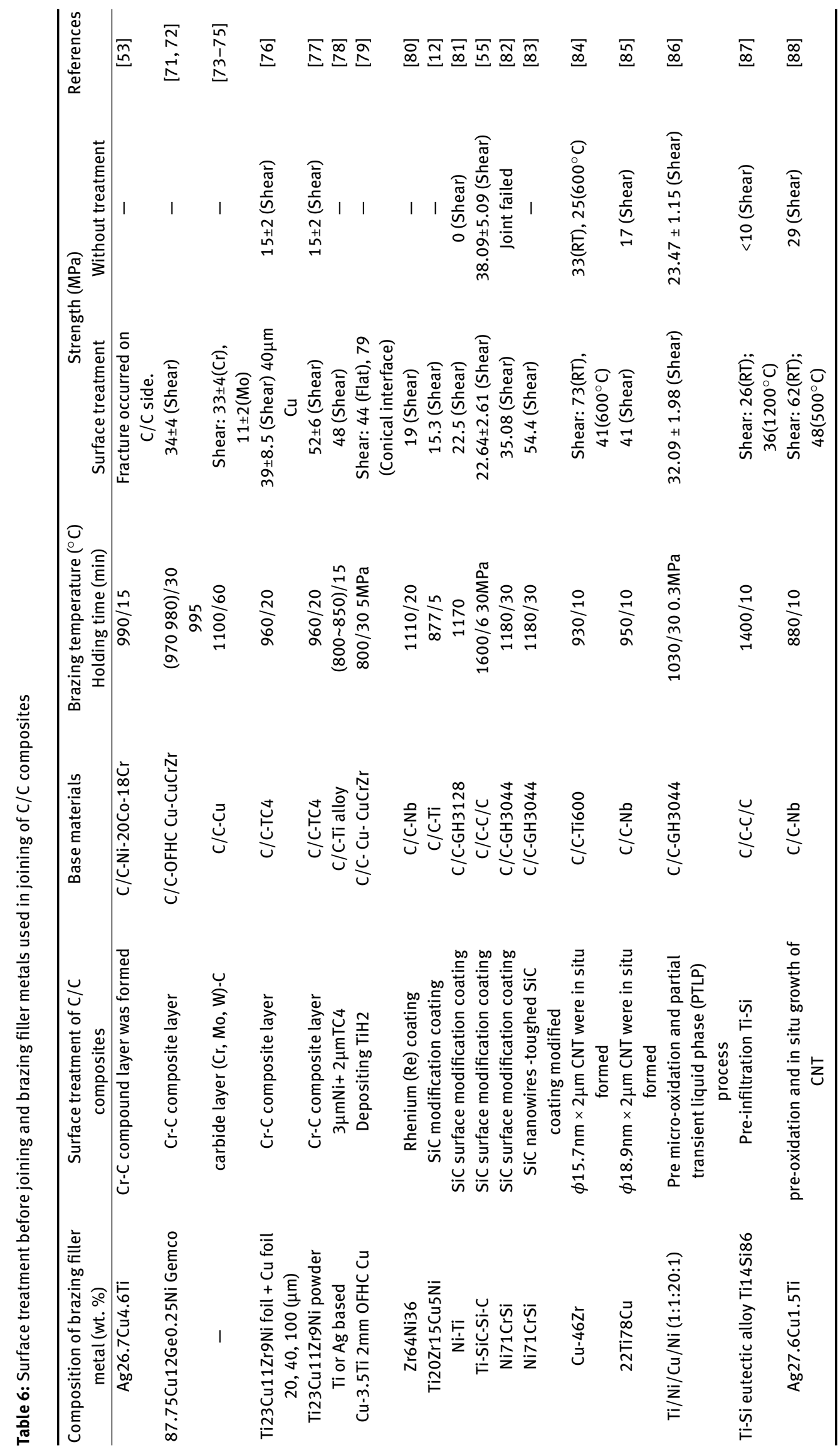




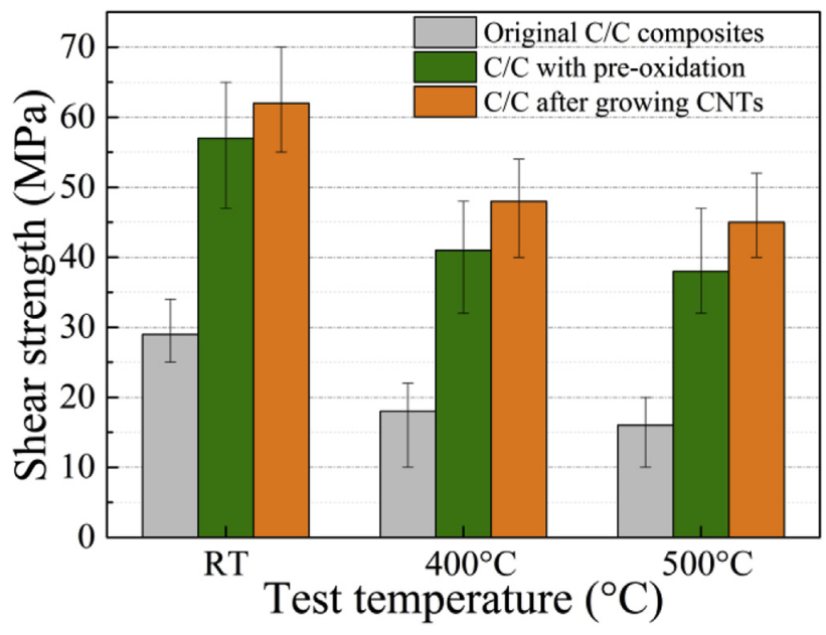

Figure 7: Shear strength of $\mathrm{Nb}-\mathrm{C} / \mathrm{C}$ joint brazed at $880^{\circ} \mathrm{C}$ for $10 \mathrm{~min}$ under different surface modification conditions of $\mathrm{C} / \mathrm{C}$ composites at different test temperatures.

its application is limited. The researches on joining of $\mathrm{C} / \mathrm{C}$ composites through surface treatment before joining are shown in Table 6.

It can be seen from Table 6 that the shear strength of joints obtained by brazing $\mathrm{C} / \mathrm{C}$ composites after surface treatment is usually higher than that of joints without surface treatment (Figure 7). Nevertheless, when the connection between the surface treatment layer and $\mathrm{C} / \mathrm{C}$ composites is poor, the fracture occurs in the surface treatment layer during shear test, the strength of the joint decreases instead. The strength of joints between surface treated C/C composites and other materials is related to the composition and thickness of surface coating, the bonding strength between $\mathrm{C} / \mathrm{C}$ composites and coating layer, and chemical reaction between coating and the brazing filler metal.

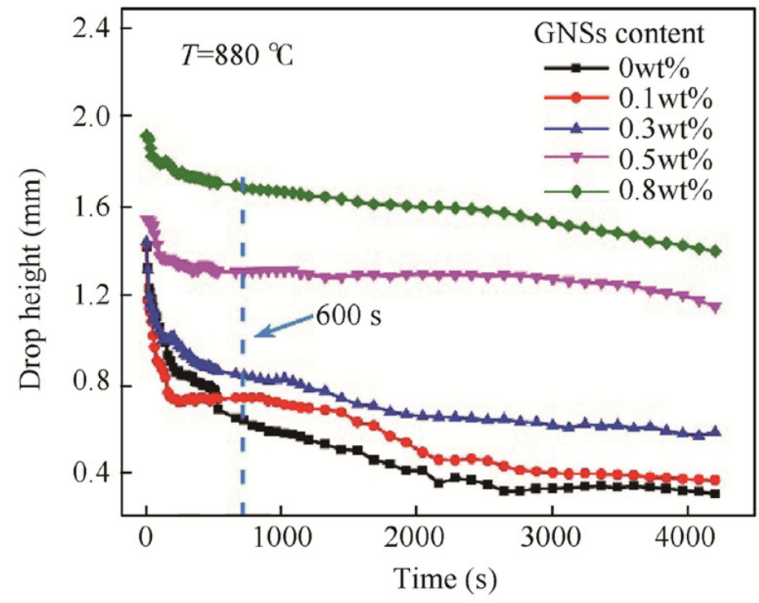

(a) Time

\section{Composite brazing filler metals}

In recent years, the single brazing filler metals cannot meet the demand of application in some aspects. In consequence, the development of new composite brazing filler metals has been widely concerned by scholars.

\subsection{Micro-nano particles reinforced composite brazing filler metals}

The performance of joint is significantly affected by the thickness of intermetallic compound layer. It is necessary to control the interface structure when joining $\mathrm{C} / \mathrm{C}$ composite, mainly the thickness of the brittle intermetallic carbide layer at the interface, which can be adjusted through changing the composition of the brazing filler metal.

It has been found that micron-sized or nano-sized particles are beneficial to improve the wettability of filler metals on C/C composite (Figure 8) [92], inhibit the growth of the reaction layer and alleviate the mismatch of thermal expansion coefficient between the brazed seam and base material, thus reducing the residual thermal stress (Figure 9) [94] and improving the mechanical properties of the joint (Figure 10) [92]. Therefore, manufacturing composite brazing filler metal with particle dispersion enhancement through adding micro-nano ceramic particles becomes an effective method to join $\mathrm{C} / \mathrm{C}$ composite. The applications of micro-nano particles reinforced composite brazing filler metals in joining of $\mathrm{C} / \mathrm{C}$ composites are shown in Table 7 .

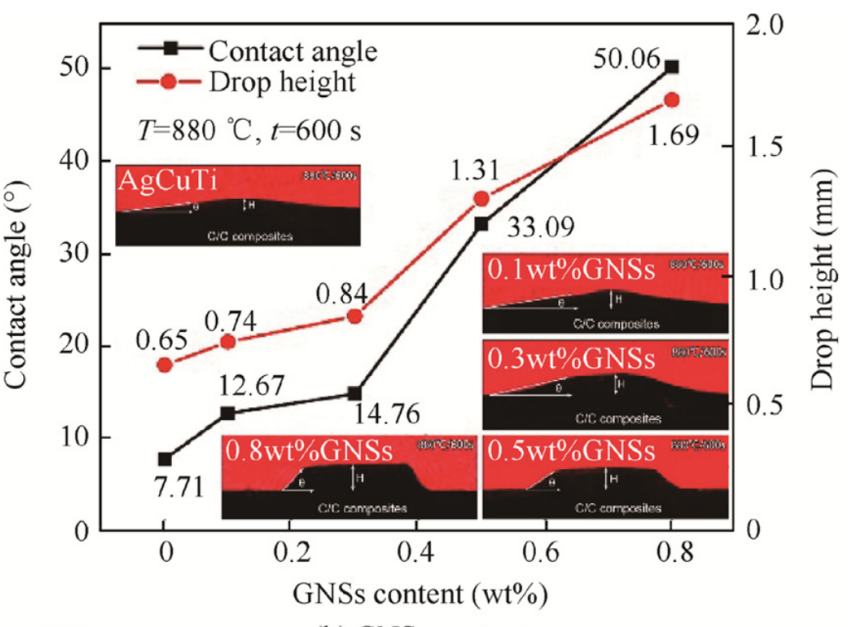

(b) GNSs content

Figure 8: Variations of drop height and contact angle with different GNS contents. 


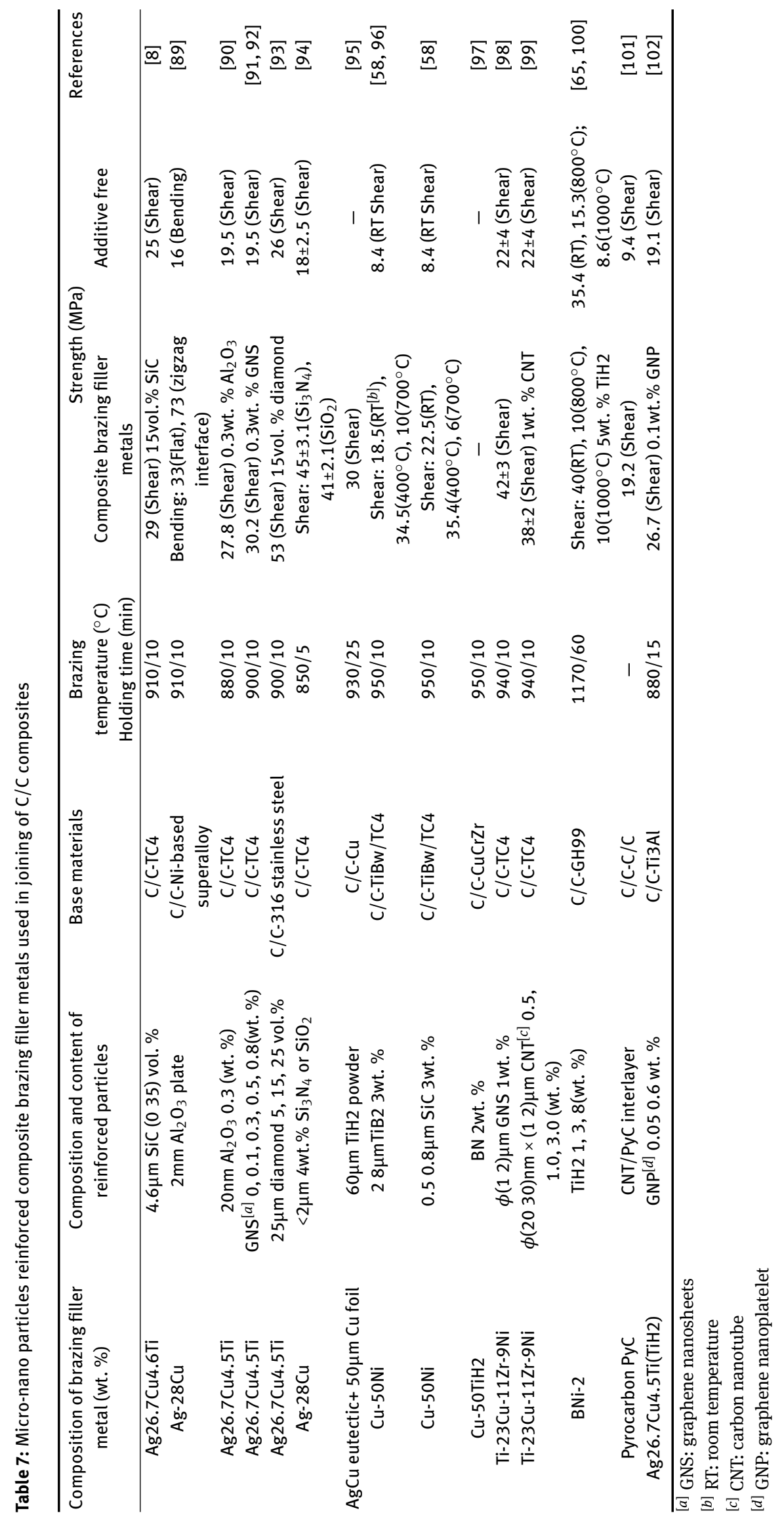




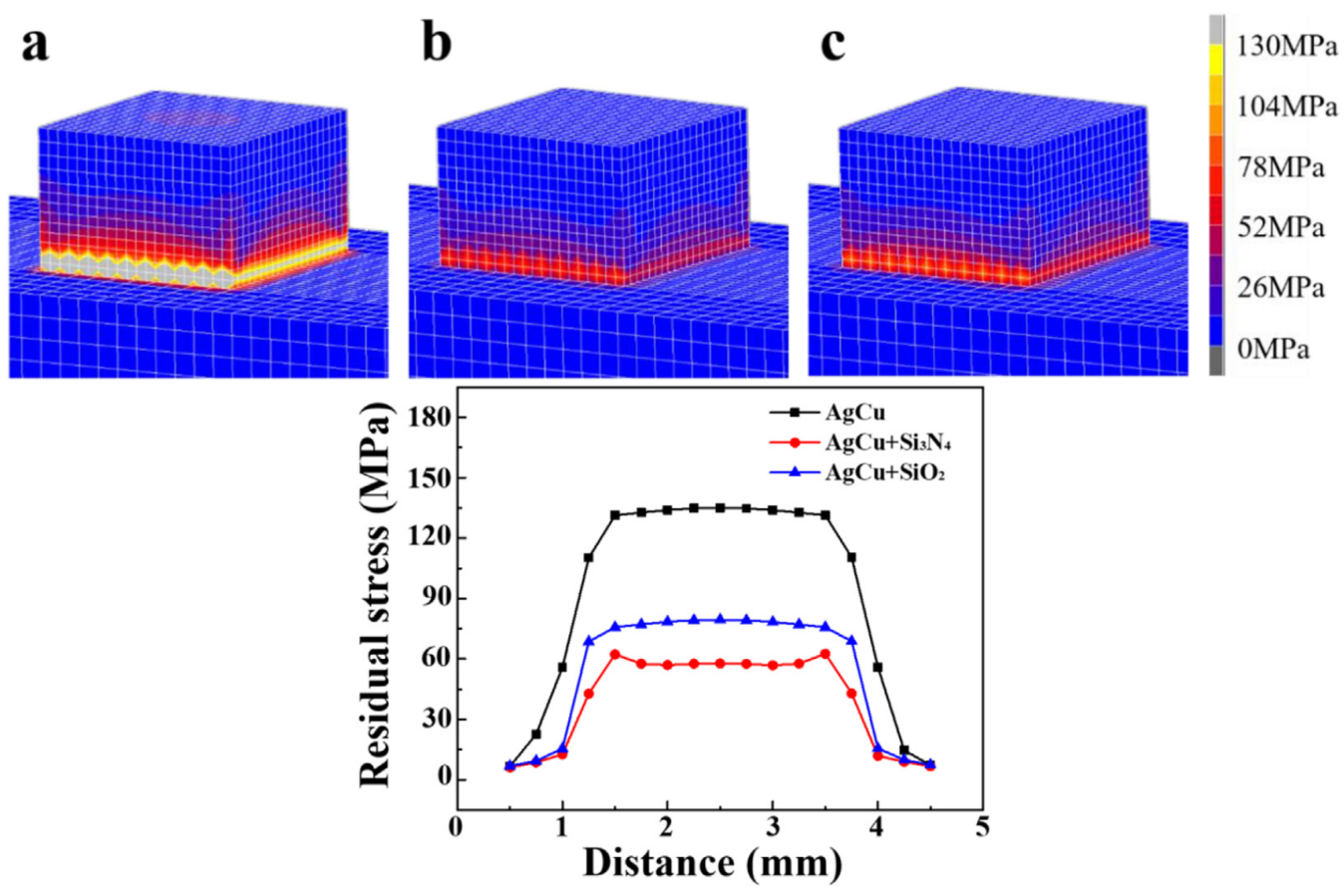

Figure 9: Distribution of equivalent Von Mises stress in joints brazed with (a) pure $\mathrm{AgCu}$, (b) $\mathrm{AgCu}+\mathrm{Si}_{3} \mathrm{~N}_{4}$, and (c) $\mathrm{AgCu}+\mathrm{SiO}_{2}$, and residual stress distribution of the middle cross-section in $\mathrm{C} / \mathrm{C}$ composites.

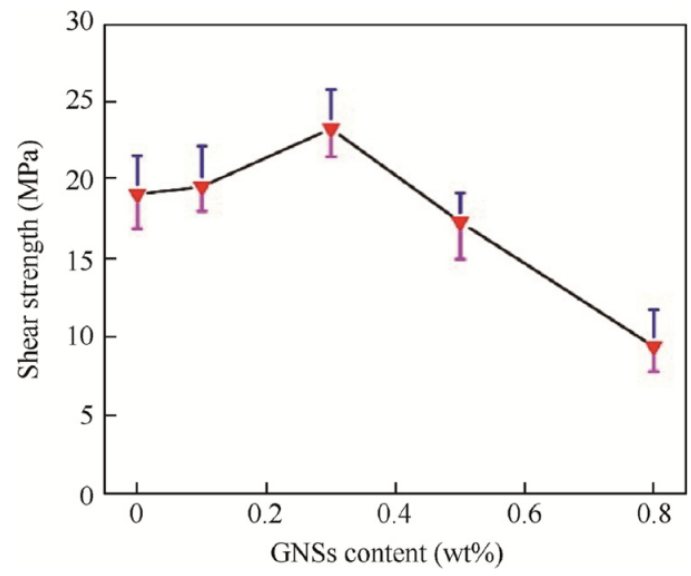

Figure 10: Effect of GNS content on the shear strength of joints $\left(\mathrm{T}=880^{\circ} \mathrm{C}, \mathrm{t}=10 \mathrm{~min}\right)$.

\subsection{Stress buffer metal interlayer added composite brazing filler metals}

While joining $\mathrm{C} / \mathrm{C}$ composites to metals, one of the important factors hindering joint performance is the large difference of thermal expansion coefficient between them (Figure 11). In order to alleviate the joint thermal stress and improve the strength of the joint, the method of inserting metal interlayer into the joint is generally adopted. Depending on the different ways of stress relief, it can be divided into soft interlayer (such as copper, aluminum and

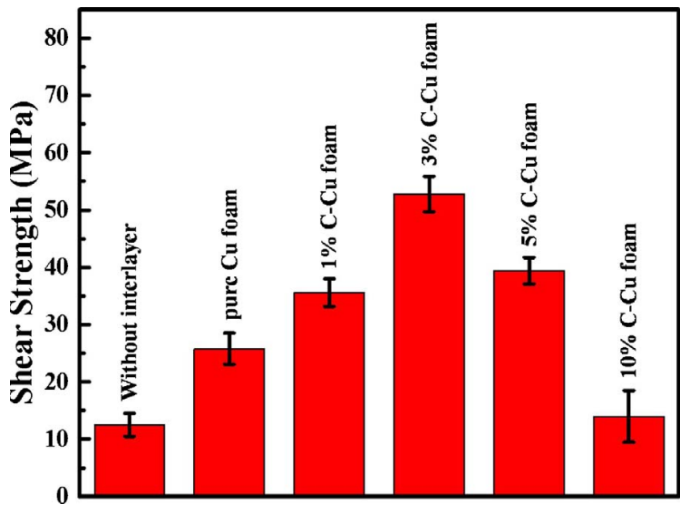

Figure 11: Effect of thickness of interlayer on shear strength at room temperature of the joints.

nickel, etc.) and hard interlayer (such as niobium, tungsten, molybdenum, etc.). The soft interlayer generally has lower elastic modulus but better plasticity. Stress can be reduced through the elasticity, plasticity and creep deformation of the metal during the joining process [23] lastic modulus of hard interlayer is generally high, and the thermal expansion coefficient is low, which is close to that of the carbon material. When joining, the residual thermal stress in the joint can be transferred to the interlayer [103] applications of stress buffer metal interlayer added composite brazing filler metals in joining of $\mathrm{C} / \mathrm{C}$ composites are shown in Table 8 . 


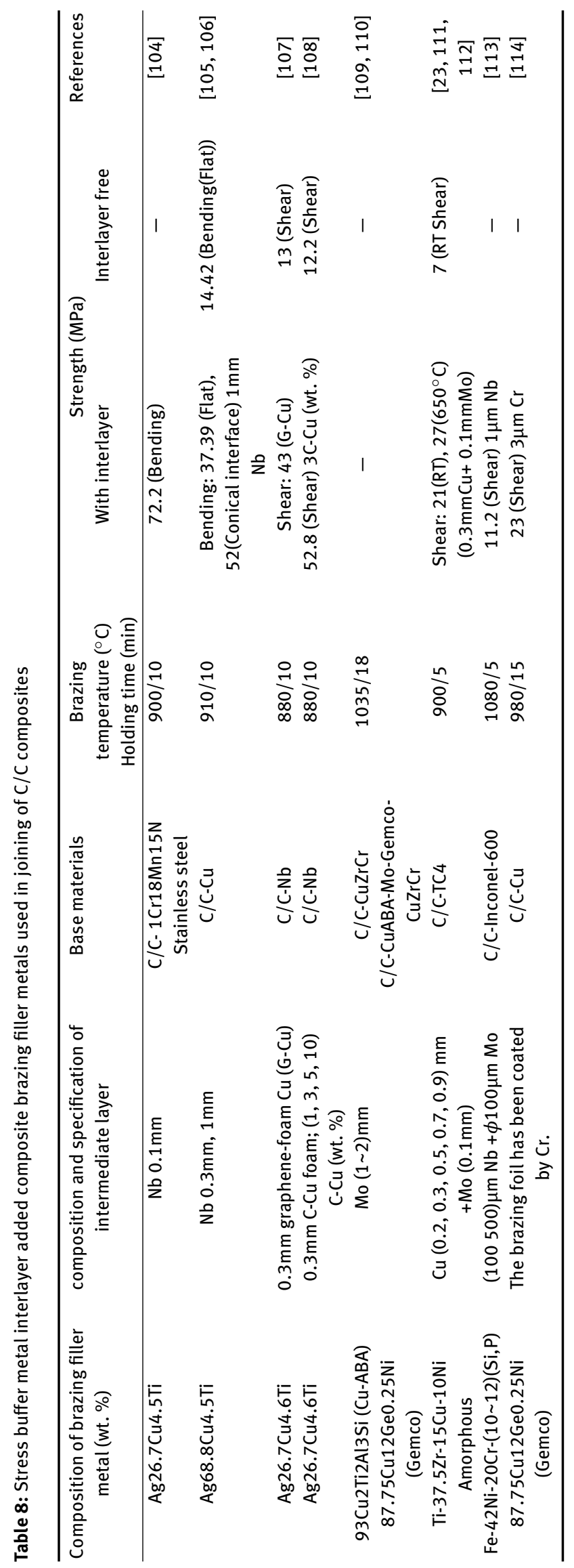




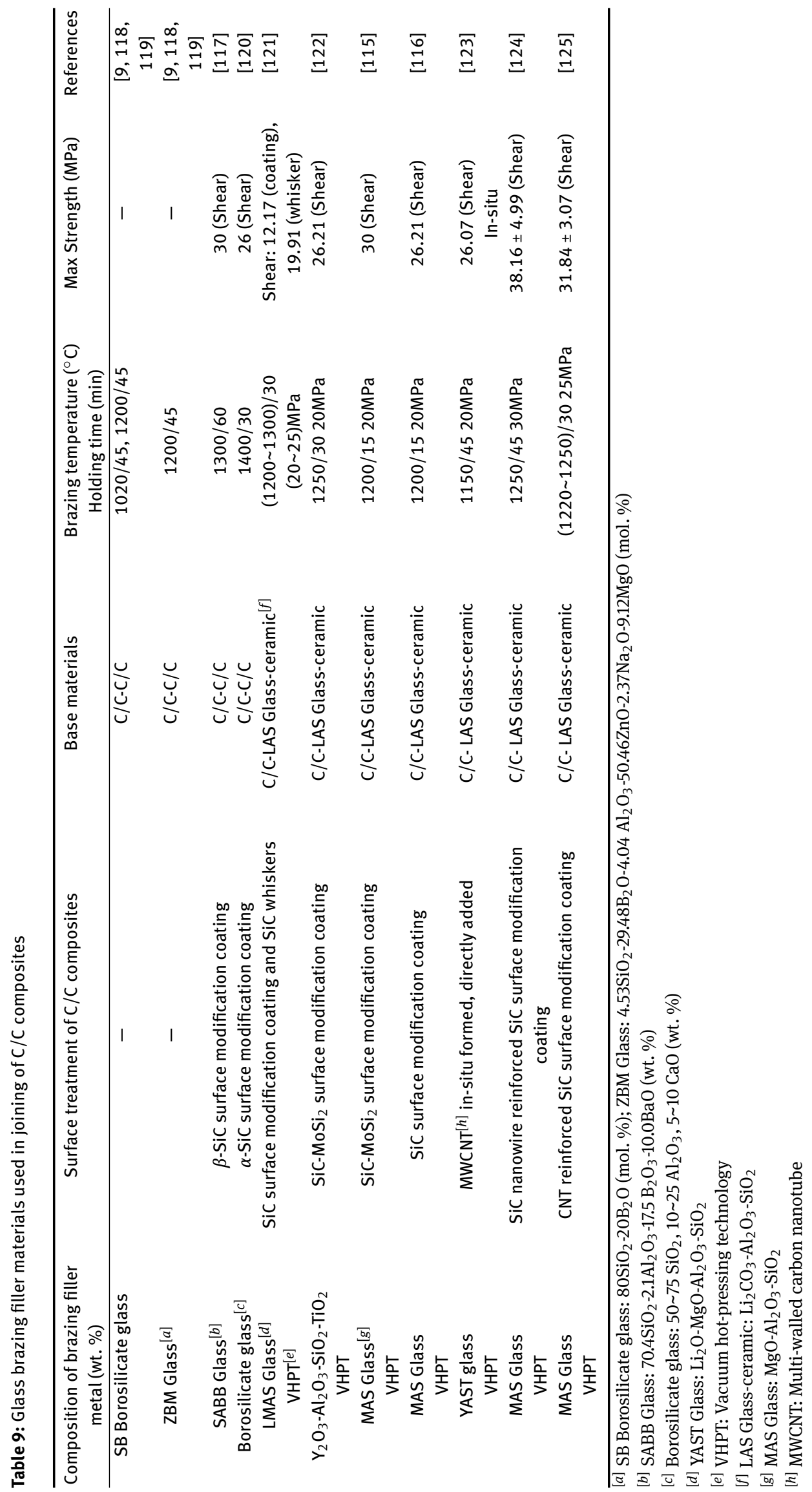




\section{Glass brazing filler materials}

Compared with other materials, glass has incomparable properties. The thermal expansion coefficient of glass material can be adjusted in a wide range. By adjusting the composition and content of the glass material, it is possible to prepare glass brazing filler that matches the thermal expansion coefficient of the base material. Meanwhile, glass ceramic materials have a series of advantages such as good thermal stability and good thermal shock resistance $[115,116]$. Glass materials have been applied in the joining of $\mathrm{C} / \mathrm{C}$ composite material itself, $\mathrm{C} / \mathrm{C}$ composites and ceramics. The applications of glass brazing fillers in joining of $\mathrm{C} / \mathrm{C}$ composites are shown in Table 9.

However, since most glass and glass-ceramic materials are difficult to wet the surface of carbon materials [117], it is difficult to give full play to its advantages in joining. Surface treatment of $\mathrm{C} / \mathrm{C}$ composites is usually required to improve wettability between brazing fillers and base materials. In consideration of good physical and chemical compatibility between $\mathrm{SiC}$ and $\mathrm{C} / \mathrm{C}$ composites and glass materials, the surface $\mathrm{SiC}$ modification of $\mathrm{C} / \mathrm{C}$ composites has become a research trend.

As can be seen from Table 9, when using glass brazing fillers to joining $\mathrm{C} / \mathrm{C}$ composites, fillers are mainly concentrated in inorganic mixed powders composed of $\mathrm{SiO}_{2}, \mathrm{~B}_{2} \mathrm{O}$, $\mathrm{Al}_{2} \mathrm{O}_{3}, \mathrm{MgO}, \mathrm{ZnO}$, and other oxides. The joining systems are also mainly the joining between $\mathrm{C} / \mathrm{C}$ composites themselves, and between $\mathrm{C} / \mathrm{C}$ and glass-ceramic materials. $\mathrm{A}$ certain amount of pressure was needed during the joining process, so as to discharge the gas, which produced by glass brazing filler due to excessive temperature, from the welding seam, and reduce the occurrence of defects.

\section{Other kinds of brazing filler materials}

Except for the above-mentioned brazing filler materials, the Si slice and $\mathrm{Mg}_{2} \mathrm{Si}$ powder can also be used to realize the joining of $\mathrm{C} / \mathrm{C}$ composite itself. The average shear strength of joints was $22 \mathrm{MPa}$ and $5 \mathrm{MPa}$, respectively [9]. The shear strength at room temperature of the joints was 20 24MPa when brazing $\mathrm{C} / \mathrm{C}$ composite itself using $\mathrm{Au}-23 \mathrm{Pd}-22 \mathrm{Ni}$ (6 12) V or Au-8Cu-30Pd-20Ni-(6 12)V. The C/C composite itself, C/C composite and TZM, C/C composite and W, C/C composite and $\mathrm{Nb}$ were brazed by $\mathrm{Cu}-(22 \sim 32) \mathrm{Pd}-(6 \sim 12) \mathrm{V}$ brazing filler metal. The shear strength of the joints at room temperature can be up to $30.6 \mathrm{MPa}, 36.9 \mathrm{MPa}, 44.8 \mathrm{MPa}$ and 21.9 MPa, respectively [126]. The shear strength of the joint of C/C composite brazed with W-(18 22)Co-(8 15)Cr(14 21)Ti was $30 \mathrm{MPa}$ at room temperature. After conical surface designing of $\mathrm{C} / \mathrm{C}$ composite, the shear strength was increased to $45 \mathrm{MPa}$ [127]. When using B powder as intermediate material to join $\mathrm{C} / \mathrm{C}$ composite and the brazing parameter was $1995^{\circ} \mathrm{C} / 15 \mathrm{~min}$, the maximum shear strength $(18.6 \pm 1.9 \mathrm{MPa})$ was obtained at $1600^{\circ} \mathrm{C}[61]$.

\section{The effect of brazing parameters on joint properties}

The brazing of $\mathrm{C} / \mathrm{C}$ composite is mainly achieved by the chemical reaction among $\mathrm{C}$ element and the chemical elements in the intermediate layer material to form a metallurgical bonding. The strength of the joint depends largely on the type, size, and distribution of the compound, that is, the reaction degree in the interface. The insufficient reaction will lead to the weakening of interfacial bonding, while excessive reaction will destroy the performance of the joint by forming more brittle compounds at the interface. It is necessary to control the interface structure when joining $\mathrm{C} / \mathrm{C}$ composite, mainly the thickness of the brittle intermetallic carbide layer at the interface, which can be adjusted through selecting appropriate process parameters. Therefore, the influence of brazing process parameters, such as temperature, heating/cooling rate and holding time, on joint strength should also be considered after the brazing material is selected.

The selection of brazing temperature should be based on the solidus and liquidus temperature of the chosen filler metal as the most important reference index. When brazing $\mathrm{C} / \mathrm{C}$ composite, in order to form a metallurgical bonding, adequate temperature is required to melt the filler metal and cause a chemical reaction at the interface. However, when the brazing temperature is too high, large number of brittle compounds will be generated in the reaction layer, which is not good for the properties of the joint. Large temperature gradient and internal stress will be caused in the base materials and joint since excessive heating or cooling rate during brazing. Excessive residual stress can seriously reduce the strength of the joint and even cause cracks at the interface between $\mathrm{C} / \mathrm{C}$ composite material and the intermediate layer materials. Adequate holding time can make sure the occurrence of metallurgical reaction and a firm joint. With the extension of holding time, the brazing joint structure tends to be homogenized. Whereas, if the holding time is too long, the thickness of the compound reaction 
layer will be increased and the performance of the joint will be reduced.

The formation of the braze joint is the result of the synergistic effect of various factors, such as temperature, heating or cooling rate, and holding time. Therefore, a robust joint can only be obtained under the appropriate process conditions. For the brazing of $\mathrm{C} / \mathrm{C}$ composite, different process parameters are needed when the joining systems and filler materials are different. Especially for the joining of heterogeneous materials, the interfacial metallurgical behavior of different materials is significantly different, and the types and distribution of the interface phases will become more complex, and the interface structure will be more difficult to explore. Generally, a large number of experiments or finite element simulation auxiliary methods should be used to explore the best process parameters.

\section{Conclusions and prospects}

In order to improve the wettability of brazing filler metals on $\mathrm{C} / \mathrm{C}$ composites, active metal elements such as $\mathrm{Ti}, \mathrm{Cr}$ and $\mathrm{V}$ which can react with $\mathrm{C}$ to form carbide are generally added to brazing filler metals, such as Al-Ti, Ag-Cu-Ti, $\mathrm{Cu}-\mathrm{Ti}, \mathrm{Cu}-\mathrm{Cr}$, Ni-Ti, Ni-Cr-P, Ni-Cr-Si-B brazing filler metals mentioned above. The active metal can react with $\mathrm{C}$ in the brazing process to generate carbide reaction layer, and the metallurgical bonding formed at the joint improves the joint strength.

Ag-based, Cu-based and Ti-based brazing filler metals are commonly used in joining of $\mathrm{C} / \mathrm{C}$ composites. They are usually used to join $\mathrm{C} / \mathrm{C}$ composite itself, $\mathrm{C} / \mathrm{C}$ composite and $\mathrm{Cu}$ alloy, $\mathrm{C} / \mathrm{C}$ composite and Ti alloy, etc. However, the joints prepared by these brazing filler metals cannot bear high temperature. Therefore, the excellent high temperature performance of $\mathrm{C} / \mathrm{C}$ composites cannot be reflected. The joints used Ni-based brazing filler metals are of high service temperature, so Ni-based brazing filler metals are usually used to connect $\mathrm{C} / \mathrm{C}$ composites and superalloys.

The research and development of composite brazing filler metals improves the shear strength of joints on the basis of traditional brazing filler metals. Composite brazing filler metals used in joining $\mathrm{C} / \mathrm{C}$ composites are mainly divided into two categories: First, adding micro-nano scale reinforcing particles, to prepare dispersion reinforced composite brazing filler metals. The second is to add a metal interlayer to cushion stress. There are three main functions of the additives, whether it is micro-nano reinforced particle or stress buffer metal interlayer. The first is to improve the wettability of brazing filler metal on the composite surface.
The other is to decrease the difference of thermal expansion coefficient between materials to reduce the residual thermal stress of the joint. Moreover, the thickness of brittle carbide layer can be reduced by adding particles or interlayer materials, which avoided the bad influence of thick reactive layer on joint strength.

At present, the joining technology of $\mathrm{C} / \mathrm{C}$ composites is still in its infancy, and joining technology and process stability are not yet mature. The brazing filler metals used in $\mathrm{C} / \mathrm{C}$ composite joining are not systematic. There are few studies on brazing filler metals which can be used in high temperature. Possible solutions include: (1) adjusting the composition of brazing filler metal and controlling the composition and thickness of interface reaction layer; (2) developing high-temperature resistance brazing filler metals which can reflect the excellent high-temperature performance of $\mathrm{C} / \mathrm{C}$ composite; (3) experimenting and developing appropriate glass brazing fillers; (4) applying new composite brazing filler metals or stress buffer interlayers. It is believed that with the further development of $\mathrm{C} / \mathrm{C}$ composites, high temperature resistance, low cost and high quality joining technologies will emerge as the times require.

Acknowledgement: This work was supported by Joint Funds of the National Natural Science Foundation of China under Grant [Nos. U1904197] and the Innovation Scientists and Technicians Troop Projects of Henan Province under Grant [Nos. ZYQR20180030].

\section{References}

[1] Savage, G. Carbon-Carbon composites. Chpman \& Hall, Great Britain, UK, 1993. https://doi.org/10.1007/978-94-011-1586-5.

[2] Fitzer, E. and L. M. Manocha. Carbon reinforcements and carbon/carbon composites. Springer-Verlag, Berlin, Germany, 1998. https://doi.org/10.1007/978-3-642-58745-0.

[3] Li, H. J. Carbon/carbon composites. New Carbon Materials, Vol. 16, 2001, pp. 79-80 (in Chinese).

[4] Chen, X. Z., Q. Y. Lu, Z. X. Zheng, W. J. Cai, K. Q. Wang, and Z. Y. Zhang. The connection mode for carbon fiber composite materials. [Natural Science Edition]. Journal of Yangzhou University, Vol. 19, 2016, pp. 33.

[5] Sun, T. and J. Y. Zhou. Summary for the connection performance of carbon fiber composite bolt. Modern Manufacturing Engineering, Vol. 09, 2018, pp. 154-160 (in Chinese).

[6] Yang, G. Research on high temperature adhesion process and mechanism of carbon materials. Master's thesis, Harbin Institute of Technology, 2014 (In Chinese).

[7] Ikeshoji, T. T. Brazing of carbon-carbon (C/C) composites to metals. Advances in brazing science, technology and applications. Woodhead, Cambridge, UK, 2013. 
[8] Qin, Y. Q. and Z. S. Yu. Joining of C/C composite to TC4 using SiC particle-reinforced brazing alloy. Materials Characterization, Vol. 61, No. 6, 2010, pp. 635-639.

[9] Salvo, M., P. Lemoine, M. Ferraris, M. Montorsi, and M. Merola. Joining of carbon-carbon composites for thermonuclear fusion applications. Journal of the American Ceramic Society, Vol. 80, No. 1, 1997, pp. 206-212.

[10] Geng, H. R., H. Li, and G. L. Chen. Microstructure and strength of $\mathrm{C} / \mathrm{C}$ composites joint with Al based brazing filler metal. Journal of Function Materials, Vol. 39, Supplement, 2008, pp. 362 (in Chinese).

[11] Wang, M., X. G. Qi, M. A. Chen, and H. R. Geng. Microstructure and properties of vacuum brazing $\mathrm{C}_{f} / \mathrm{C}$ composites using reactive $\mathrm{Al}$ based filler metals. Hot Working Technology, Vol. 38, 2009, pp. 180-182 (in Chinese).

[12] L. X. Deng. Study on interface microstructure and joining mechanism of $\mathrm{C} / \mathrm{C}$ composite materials active brazing joints. Master's thesis, Central South University, 2011 (in Chinese).

[13] Wu, C. P., D. Q. Yi, C. H. Xu, J. M. Zhou, and Z. Weng. Present research situation and development trend of silver alloys. Electrical Engineering Materials., Vol. 2, 2012, pp. 1 (In Chinese).

[14] Cao, X. J., Y. Zhu, W. Guo, P. Peng, and K. T. Ma. Microstructure and Mechanical Properties of $\mathrm{C} / \mathrm{C}$ composite/TC17 Joints with Ag-Cu-Ti Brazing Alloy. Materials Science and Engineering, Vol. 275, 2017, pp. 12.

[15] Liu, S. Y. and Y. C. Shin. Simulation and experimental studies on microstructure evolution of resolidified dendritic TiCx in laser direct deposited Ti-TiC composite. Materials \& Design, Vol. 159, 2018, pp. 212-223.

[16] Qin, Y. Q., J. C. Feng, and L. X. Zhang. Microstructure and fracture properties of carbon/carbon composite and TC4 titanium alloy joints. Transactions of the China Welding Institution., Vol. 03 , 2007, pp. 13-16 (in Chinese).

[17] Guo, W., L. Wang, Y. Zhu, and P. K. Chu. Microstructure and mechanical properties of $\mathrm{C} / \mathrm{C}$ composite/TC4 joint with inactive AgCu filler metal. Ceramics International, Vol. 41, No. 5, 2015, pp. 7021-7027.

[18] Okamura H., S. J. Kajiura, and M. Akiba. Bonding between carbon fiber/carbon composite and copper alloy. Quarterly journal of the Japan Welding Society. Vol. 14, 1996, pp. $39-46$ (in Japanese).

[19] Ma, W. L., W. Mao, X. H. Li, and Y. Y. Cheng. The vacuum brazing of carbon/carbon composite using silver-based active filler metal. Journal of Materials Engineering, Vol. 01, 2002, pp. 9 (in Chinese).

[20] Morscher, G. N., M. Singh, T. P. Shpargel, and R. Asthana. A simple test to determine the effectiveness of different braze compositions for joining Ti tubes to $\mathrm{C} / \mathrm{C}$ composite plates. Materials Science and Engineering A, Vol. 418, No. 1-2, 2006, pp. 19-24.

[21] Singh, M., G. N. Morscher, T. P. Shpargel, and R. Asthana. Effect of composite substrate properties on the mechanical behavior of brazed joints in metal-composite system. Abstract for $3 \mathrm{rd} \mathrm{In-}$ ternational Brazing and Soldering Conference April 24-26, 2006, TX, San Antonio, USA.

[22] Singh, M., T. P. Shpargel, G. N. Morscher, and R. Asthana. Active metal brazing and characterization of brazed joints in titanium to carbon-carbon composites. Materials Science and Engineering A, Vol. 412, No. 1-2, 2005, pp. 123-128.

[23] Y. Q. Qin. Study on microstructure and mechanical properties of $\mathrm{C} / \mathrm{C}$ composite and TC4 brazed joint. PhD thesis, Harbin Institute of Technology, 2007 (in Chinese).
[24] Qin, Y. Q., J. C. Feng, and L. X. Zhang. Microstructure and mechanical properties of carbon/carbon composites and TC4 joints. Rare Metal Materials and Engineering, Vol. 36, 2007, pp. 1210-1214 (in Chinese).

[25] Qin, Y. Q. and J. C. Feng. Microstructure and mechanical properties of $\mathrm{C} / \mathrm{C}$ composite/TC4 joint using AgCuTi filler metal. Materials Science and Engineering A, Vol. 454, 2006, pp. 322-327.

[26] Singh, M., R. Asthana, and T. P. Shpargel. Brazing of carboncarbon composites to $\mathrm{Cu}$-clad molybdenum for thermal management applications. Materials Science and Engineering A, Vol. 452-453, 2007, pp. 699-704.

[27] Singh, M. and R. Asthana. Characterization of brazed joints of $\mathrm{C}-\mathrm{C}$ composite to Cu-clad-Molybdenum. Composites Science and Technology, Vol. 68, No. 14, 2008, pp. 3010-3019.

[28] Singh, M., G. N. Morscher, T. P. Shpargel, and R. Asthana. Active metal brazing of titanium to high-conductivity carbon-based sandwich structures. Materials Science and Engineering A, Vol. 498, No. 1-2, 2008, pp. 31-36.

[29] Wang, H. Q., J. Cao, and J. C. Feng. Brazing mechanism and infiltration strengthening of $\mathrm{C} / \mathrm{C}$ composites to TiAl alloys joint. Scripta Materialia, Vol. 63, No. 8, 2010, pp. 859-862.

[30] Wang, L., K. K. Wang, W. Guo, Y. Zhu, P. Qu, H. Kang, et al. Research on the brazing of carbon-carbon composite and Ni-based superalloy K24. Proceedings of the 16th national welding academic conference, April, 2011, Jiangsu, China (in Chinese).

[31] Ikeshoji, T. T., T. Amanuma, A. Suzumura, and T. Yamazaki. Shear strength of brazed joint between titanium and $\mathrm{C} / \mathrm{C}$ composites with various cross-ply angles. Journal of Solid Mechanics and Materials Engineering, Vol. 05, No. 12, 2011, pp. 1022-1028.

[32] Li, J. K., X. Liu, and J. E. Zhou. Microstructure and mechanical performances of $\mathrm{C} / \mathrm{C}$ composite and TC4 alloy brazed joints. Key Engineering Materials, Vol. 512-515, 2012, pp. 415-420.

[33] Guo, W., Y. Zhu, L. Wang, P. Qu, H. Kang, and P. K. Chu. Microstructure evolution and mechanical properties of vacuum-brazed $\mathrm{C} / \mathrm{C}$ composite with AgCuTi foil. Materials Science and Engineering A, Vol. 564, 2013, pp. 192-198.

[34] Zhou, X. G., F. Q. Zhang, Q. Yu, and L. H. Xia. Microstructure analyses on joint of carbon/carbon composites and titanium ally using Ag-Cu-Ti as brazing metal. Materials Research and Application, Vol. 7, 2013, pp. 67 (in Chinese).

[35] Yang, L. Y., M. Z. Yi, L. P. Ran, Y. C. Ge, and K. Peng. Joining of carbon/carbon composite using AgCuTi braze. Materials Science and Engineering of Powder Metallurgy, Vol. 20, 2015, pp. 765 (in Chinese).

[36] Guo, W., T. F. Gao, X. F. Cui, Y. Zhu, and P. K. Chu. Interfacial reactions and zigzag groove strengthening of $\mathrm{C} / \mathrm{C}$ composite and Rene N5 single crystal brazed joint. Ceramics International, Vol. 41, No. 9, 2015, pp. 11605-11610.

[37] Zhang, K. X., L. H. Xia, F. Q. Zhang, and L. L. He. Active brazing of $\mathrm{C} / \mathrm{C}$ composite to copper by AgCuTi filler metal. Metallurgical and Materials Transactions. A, Physical Metallurgy and Materials Science, Vol. 47A, No. 5, 2016, pp. 2162-2176.

[38] Gotoh, Y., H. Okamura, S. Kajiura, M. Kumagai, T. Ando, M. Akiba, et al. Development and material testing of OF-Cu/DS-Cu/OF-Cu triplex tube and trial fabrication of a vertical target mock-up for ITER divertor. Journal of Nuclear Materials, Vol. 258-263, 1998, pp. 271-274.

[39] Wang, Y. L., W. L. Wang, J. H. Huang, R. H. Yu, J. Yang, and S. H. Chen. Reactive composite brazing of $\mathrm{C} / \mathrm{C}$ composite and $\mathrm{GH} 3044$ with Ag-Ti mixed powder filler material. Materials Science and 
Engineering A, Vol. 759, 2019, pp. 303-312.

[40] Eustathopoulos, N., M. G. Nicholas, and B. Drevet. Wettability at Hightemperatures. Pergamon, Boston, USA, 1999.

[41] Casalegno, V., M. Salvo, S. Murdaca, and M. Ferraris. One-step brazing process for CFC monoblock joints and mechanical testing. Journal of Nuclear Materials, Vol. 393, No. 2, 2009, pp. 300-305.

[42] Li, J. G. Kinetics of wetting and spreading of $\mathrm{Cu}-\mathrm{Ti}$ alloys on alumina and glassy carbon substrates. Journal of Materials Science Letters, Vol. 11, No. 23, 1992, pp. 1551-1554.

[43] Li, H., H. R. Geng, G. L. Chen, J. H. Chen, and M. A. Chen. Microstructure and strength of $C_{f} / C$ composites joint brazed with $\mathrm{Cu}$ based brazing filler metal. Welding \& Jioning, Vol. 01, 2008, pp. 42 (in Chinese).

[44] Yi, Z. H., K. Z. Yang, J. Xiang, F. M. Liu, and S. Y. Zhao. Experimental research on Ti-Cu brazing filler for $\mathrm{C} / \mathrm{C}$ composites. Materials Research and Application, Vol. 03, 2008, pp. 215 (in Chinese).

[45] Chen, J. H. Microstructure and properties of brazed joint of $C_{f} / C$ composite by vacuum brazing using $\mathrm{Cu}$ based active brazed filler. Material and Heat Treatment, Vol. 39, 2010, pp. 94 (in Chinese).

[46] Li, J. L., J. T. Xiong, and F. S. Zhang. Transient liquid-phase diffusion bonding of two-dimensional carbon-carbon composites to niobium alloy. Materials Science and Engineering A, Vol. 483484, 2008, pp. 698-700.

[47] Salvo, M., P. Lemoine, M. Ferraris, M. A. Montorsi, and R. Matera. $\mathrm{Cu}-/ \mathrm{Pb}$ rheocast alloy as joining material for CFC composites. Journal of Nuclear Materials, Vol. 226, No. 1-2, 1995, pp. 67-71.

[48] Koppitz, Th., G. Pintsuk, U. Reisgen, J. Remmel, T. Hirai, R. Sievering, et al. High-temperature brazing for reliable tungsten-CFC joints. Physica Scripta, Vol. 128, 2007, pp. 175-181.

[49] Liu, J. Y. Brazing of carbon-carbon composites: filler metals and techniques for brazing C-C composite to metals. PhD thesis, Auburn University, 1993.

[50] Liu, J. Y., S. Chen, and B. A. Chin. Brazing of vanadium and carboncarbon composites to stainless steel for fusion reactor applications. Journal of Nuclear Materials, Vol. 212, 1994, pp. 15901593.

[51] Trester, P. W., P. G. Valentine, W. R. Johnson, E. Chin, E. E. Reis, and A. P. Colleraine. Tensile fracture characterization of braze joined copper-to-CFC coupon as assemblies. Journal of Nuclear Materials, Vol. 233-237, 1996, pp. 906-912.

[52] Luo, Y., H. Bian, H. W. Niu, Y. Y. Song, Z. B. Chen, X. G. Song, and M. R. Wang. Interfacial microstructure and mechanical properties of $\mathrm{C} / \mathrm{C}$ composites and $\mathrm{Nb}$ joints brazed with Cu75Pt25 filler metal. Vacuum, Vol. 157, 2018, pp. 202-209.

[53] Lauf, R. J., A. D. McMillan, and A. J. Moorhead. Method for joining carbon-carbon composites to metals. US. Patent 5648180, 1997.

[54] Wang, J., K. Z. Li, X. R. Song, L. J. Guo, W. Li, and Z. Q. Li. The study on joining carbon/carbon composites using Ti-Ni-Si compound. Materials Science and Engineering A, Vol. 547, 2012, pp. 12-18.

[55] Wang, J., K. Z. Li, W. Li, H. J. Li, Z. Q. Li, and L. J. Guo. The preparation and mechanical properties of carbon/carbon composite joints using Ti-Si-SiC-C filler as interlayer. Materials Science and Engineering A, Vol. 574, 2013, pp. 37-45.

[56] Appendino, P., V. Casalegno, M. Ferraris, M. Grattarola, M. Merola, and M. Salvo. Joining of $\mathrm{C} / \mathrm{C}$ composites to copper. Fusion Engineering and Design, Vol. 68, 2003, pp. 225-229.

[57] Branca, V., A. Federici, and M. Grattarola. The brazing technology for high heat flux components. 10th International Workshop on Carbon Materials for Fusion Applications, September 17-19, 2003, ü̈lich, Germany.
[58] Huang, C. Brazing bonding processes and interface behavior of C/C composite and TiBw/TC4 alloy. Master's thesis, Harbin Institute of Technology, 2010 (in Chinese).

[59] Xu, L. G. Study on technology and mechanism of brazing C/C composite to niobium. Master's thesis, Harbin Institute of Technology, 2013 (in Chinese).

[60] Cao, J., Z. J. He, J. L. Qi, H. Q. Wang, and J. C. Feng. Brazing of $\mathrm{C} / \mathrm{C}$ composite to TiAl alloy using $(\mathrm{Ti} / \mathrm{Ni} / \mathrm{Cu}) \mathrm{f}$ multi-foil filler. Jixie Gongcheng Xuebao, Vol. 54, No. 1, 2018, pp. 108-114 (in Chinese).

[61] Dadras, P., T. T. Ngai, and G. M. Mehrotra. Joining of carboncarbon composites using boron and titanium disilicide interlayers. Journal of the American Ceramic Society, Vol. 80, No. 1, 1997, pp. 125-132.

[62] Wang, J., G. Z. Yang, F. Q. Zhang, Y. L. Xiong, and Q. L. Xiong. The preparation and mechanical properties of carbon/carbon $(\mathrm{C} / \mathrm{C})$ composite and carbon fiber reinforced silicon carbide $\left(\mathrm{C}_{f} / \mathrm{SiC}\right)$ composite joint by partial transient liquid phase (PTLP) diffusion bonding process. Vacuum, Vol. 158, 2018, pp. 113-116.

[63] Ma, W. L., W. Mao, and X. H. Li. The brazing of carbon/carbon composite using Ni-based high-temperature filler metal. Proceedings of the 10th National Welding Academic Conference, March, 2001, China (in Chinese).

[64] Singh, M., R. Asthana, and T. P. Shpargel. Brazing of ceramicmatrix composites to $\mathrm{Ti}$ and hastealloy using $\mathrm{Ni}$-base metallic glass interlayers. Materials Science and Engineering A, Vol. 498, No. 1-2, 2008, pp. 19-30.

[65] Tian, X. Y. Technical and mechanism study on brazing of C/C composites to GH99 nickel-base superalloy. Master's thesis, Harbin Institute of Technology, 2010 (in Chinese).

[66] Guo, L. J., C. Guo, H. J. Li, and K. Z. Li. Mechanical properties and microstructure of the joints between carbon-carbon composites and $\mathrm{Ni}$ based high temperature alloys. Rare Metal Materials and Engineering, Vol. 40, 2011, pp. 111-114 (in Chinese).

[67] Zhang, S. M., K. Z. Li, J. Wang, X. R. Song, and L. J. Guo. PTLP bonding $\mathrm{C} / \mathrm{C}$ composites to super-alloy $\mathrm{GH} 3044$ with $\mathrm{Ni} / \mathrm{Ti}$ interlayer. Journal of Solid Rocket Technology., Vol. 35, 2012, pp. 414-418 (in Chinese).

[68] Feng, Z. W., T. F. Gao, T. W. Shao, W. Guo, Y. Zhu, and P. Qu. Brazing of $\mathrm{C} / \mathrm{C}$ composite and $\mathrm{Ni}$-based high temperature alloy $\mathrm{GH} 3128$. Transactions of the China Welding Institution., Vol. 36, 2015, pp. 105 (in Chinese).

[69] Wu, Y. Z., H. G. Li, L. Q. Ning, J. Y. Mao, and J. X. Bi. Microstructure and property analysis of the vacuum brazed carbon-carbon composites and high temperature alloy joint. Aerospace Materials \& Technology, Vol. 1, 2015, pp. 69 (in Chinese).

[70] Shi, J. M., L. X. Zhang, X. Y. Tian, H. W. Li, and J. C. Feng. Vacuum brazing of the $C_{f} / C$ composite and Ni base superalloy using MBF 20 filler. Vacuum, Vol. 156, 2018, pp. 427-433.

[71] Pintsuk, G., V. Casalegno, M. Ferraris, T. Koppitz, and M. Salvo. Thermal fatigue characterization of CFC divertor modules using a one-step brazing process. Journal of Nuclear Materials, Vol. 426, No. 1-3, 2012, pp. 78-84.

[72] Salvo, M., V. Casalegno, S. Rizzo, F. Smeacetto, M. Ferraris, and M. Merola. One-step brazing process to join CFC composites to copper and copper alloy. Journal of Nuclear Materials, Vol. 374, No. 1-2, 2008, pp. 69-74.

[73] Appendino, P., M. Ferraris, V. Casalegno, M. Salvo, M. Merola, and M. Grattarola. Proposal for a new technique to join CFC composites to copper. Journal of Nuclear Materials, Vol. 348, No. 1-2, 2006, pp. 102-107. 
[74] Appendino, P., M. Ferraris, V. Casalegno, M. Salvo, M. Merola, and M. Grattarola. Direct joining of CFC to copper. Journal of Nuclear Materials, Vol. 329-333, 2004, pp. 1563-1566.

[75] Casalegno, V., M. Salvo, and M. Ferraris. Surface modification of carbon/ carbon composites to improve their wettability by copper. Carbon, Vol. 50, No. 6, 2012, pp. 2296-2306.

[76] Song, X. R., H. J. Li, V. Casalegno, M. Salvo, M. Ferraris, and $X$. R. Zeng. Microstructure and mechanical properties of $\mathrm{C} / \mathrm{C}$ composite/Ti6Al4V joints with a $\mathrm{Cu} / \mathrm{TiCuZrNi}$ composite brazing alloy. Ceramics International, Vol. 42, No. 5, 2016, pp. 63476354.

[77] Song, X. R., H. J. Li, V. Casalegno, M. Salvo, M. Ferraris, and X. R. Zeng. In situ TiC particle reinforced TiCuZrNi brazing alloy for joining C/C composites to Ti6Al4V. International Journal of Applied Ceramic Technology, Vol. 15, No. 3, 2018, pp. 611-618.

[78] Li, Z. X., L. Zhou, Z. Xu, Y. F. Zhang, and J. H. Du. A method for joining carbon matrix composite materials with titanium alloys. China, 2002, id. 02116859.8 (in Chinese).

[79] Shen, Y. X., Z. L. Li, C. Y. Hao, and J. S. Zhang. Joining C/C composite to copper using active Cu-3.5Si braze. Journal of Nuclear Materials, Vol. 421, No. 1-3, 2012, pp. 28-31.

[80] Zhang, L. X., C. L. Tian, X. Y. Tian, J. C. Feng, J. S. Shi, and Y. C. Liang. Research on vacuum brazing of C/C-Re composite to $\mathrm{Nb}$. Transactions of the China Welding Institution., Vol. 36, 2015, pp. 47 (in Chinese).

[81] Guo, L. J., H. J. Li, C. Guo, K. Z. Li, and T. Feng. Joining of C/C Composites and GH3128 Ni-based superalloy with $\mathrm{Ni}$-Ti mixed powder as an interlayer. Rare Metal Materials and Engineering, Vol. 40, No. 12, 2011, pp. 2088-2091.

[82] Zhang, X., X. H. Shi, J. Wang, H. J. Li, and K. Z. Li. Brazing of C/C composites and $\mathrm{GH} 3044 \mathrm{Ni}$-based superalloy using Ni71CrSi as the interlayer. Materials China, Vol. 32, 2013, pp. 665-670 (in Chinese)

[83] Shi, X. H., X. X. Jin, H. J. Lin, J. Y. Jing, L. Li, and C. C. Wang. Joining of $\mathrm{SiC}$ nanowires-toughened $\mathrm{SiC}$ coated $\mathrm{C} / \mathrm{C}$ composites and nickel based superalloy (GH3044) using Ni71CrSi interlayer. Journal of Alloys and Compounds, Vol. 693, 2017, pp. 837-842.

[84] Zhu, Y. A. Research on the growth of CNTs on C/C composite and the process and mechanism of brazing with Ti600 alloy. Master's thesis, Harbin Institute of Technology, 2016 (in Chinese).

[85] Song, Y. H. Research on the growth of CNTs on C/C composite and the process and mechanism of brazing with Nb. Master's thesis, Harbin Institute of Technology, 2017 (in Chinese).

[86] Shi, X. H., X. X. Jin, N. N. Yan, and L. Yang. Influence of microoxidation on joints of $\mathrm{C} / \mathrm{C}$ composites and $\mathrm{GH} 3044$ for large-size aerospace parts. Acta Astronautica, Vol. 140, 2017, pp. 478-484.

[87] He, Z. J., C. Li, J. L. Qi, Y. X. Huang, J. C. Feng, and J. Cao. Preinfiltration and brazing behaviors of $\mathrm{C}_{f} / \mathrm{C}$ composites with high temperature Ti-Si eutectic alloy. Carbon, Vol. 140, 2018, pp. 5767.

[88] Yang, Z. W., C. L. Wang, Y. Han, Y. T. Zhao, Y. Wang, and D. P. Wang. Design of reinforced interfacial structure in brazed joints of $C / C$ composites and $\mathrm{Nb}$ by pre-oxidation surface treatment combined with in situ growth of CNTs. Carbon, Vol. 143, 2019, pp. 494-506.

[89] Shen, Y. X., Z. L. Li, C. Y. Hao, and J. S. Zhang. A novel approach to brazing $\mathrm{C} / \mathrm{C}$ composite to $\mathrm{Ni}$-based superalloy using alumina interlayer. Journal of the European Ceramic Society, Vol. 32, No. 8, 2012, pp. 1769-1774.

[90] Zhou, Y. H., D. Liu, H. W. Niu, X. G. Song, X. D. Yang, and J. C. Feng. Vacuum brazing of $\mathrm{C} / \mathrm{C}$ composite to $\mathrm{TC} 4$ alloy using nano- $\mathrm{Al}_{2} \mathrm{O}_{3}$ strengthened AgCuTi composite filler. Materials \& Design, Vol. 93, 2016, pp. 347-356.

[91] Zhou, Y. H., D. Liu, X. G. Song, J. H. Liu, Y. Y. Song, Z. Wang, et al. Characterization of carbon/carbon composite/Ti6Al4V joints brazed with graphene nanosheets strengthened AgCuTi filler. Ceramics International, Vol. 43, No. 18, 2017, pp. 16600-16610.

[92] Liu, D., Y. Y. Song, Y. H. Zhou, X. G. Song, W. Fu, and J. C. Feng. Brazing of $C / C$ composite and Ti- $6 \mathrm{Al}-4 \mathrm{~V}$ with graphene strengthened AgCuTi filler: Effects of graphene on wettability, microstructure and mechanical properties. Chinese Journal of Aeronautics, Vol. 31, No. 7, 2018, pp. 1602-1608.

[93] Zhang, S. Y., Y. Yuan, Y. Y. Su, and X. R. Song. Interfacial microstructure and mechanical properties of brazing carbon/carbon composites to stainless steel using diamond particles reinforced Ag-Cu-Ti brazing alloy. Journal of Alloys and Compounds, Vol. 719, 2017, pp. 108-115.

[94] Ba, J., Y. H. Wang, Y. L. Liu, J. H. Lin, J. L. Qi, G. Wang et al. In situ consume excessive Ti element and form fine Ti based compounds as reinforcements for strengthening C/C-TC4 joints. Vacuum, Vol. 143, 2017, pp. 303-311.

[95] Zhao, L., J. B. Hou, and X. H. Li. Active cement added brazing of $\mathrm{C}_{f} / \mathrm{C}$ composites to copper. Welding Journal, Vol. 01, 2018, pp. 46 (in Chinese).

[96] Lin, T. S., M. X. Yang, P. He, C. Huang, P. Pan, and Y. D. Huang. Effect of in situ synthesized TiB whisker on microstructure and mechanical properties of carbon-carbon composite and TiBw/Ti6Al-4V composite joint. Materials \& Design, Vol. 32, No. 8-9, 2011, pp. 4553-4558.

[97] Yu, S. Research on joining of carbon materials to CuCrZr alloys with Cu-based fillers. Master's thesis, Wuhan Institute of Technology, 2016 (in Chinese).

[98] Song, X. R., H. J. Li, X. R. Zeng, and L. L. Zhang. Brazing of C/C composites to Ti6Al4V using graphene nanoplatelets reinforced TiCuZrNi brazing alloy. Materials Letters, Vol. 183, 2016, pp. 232235.

[99] Song, X. R., H. J. Li, and X. R. Zeng. Brazing of C/C composites to Ti6Al4V using multiwall carbon nanotubes reinforced TiCuZrNi brazing alloy. Journal of Alloys and Compounds, Vol. 664, 2016, pp. $175-180$.

[100] Tian, X. Y., J. L. Qi, L. X. Zhang, Y. C. Liang, H. W. Li, and J. C. Feng. Brazing of $\mathrm{C} / \mathrm{C}$ composite and $\mathrm{GH} 99$ superalloy using $\mathrm{BNi}_{2}+\mathrm{TiH}_{2}$ composite filler powder. Transactions of the China Welding Institution, Vol. 35, 2014, pp. 35-38 (in Chinese).

[101] Feng, L., K. Z. Li, B. Xue, Q. Song, X. R. Song, and Q. G. Fu. Joining carbon/carbon composites with radially-aligned carbon nanotube reinforced pyro-carbon bonding interlayer. Materials Letters, Vol. 187, 2017, pp. 158-161.

[102] Guo, W., H. Q. Zhang, W. Q. Yuan, Y. Zhu, H. Zhang, P. Peng et al. The microstructure and mechanical properties of $\mathrm{C} / \mathrm{C}$ composite/ $\mathrm{Ti}_{3} \mathrm{Al}$ alloy brazed joint with graphene nanoplatelet strengthened Ag-Cu-Ti filler. Ceramics International, Vol. 45, No. 7, 2019, pp. 8783-8789.

[103] Zhang, Y., Z. Y. He, and D. Feng. Recent progress of interlayer used to join metals and ceramics. Journal of Iron and Steel Research., Vol. 19, 2007, pp. 1-4 (in Chinese).

[104] Ou, X. X., F. Q. Zhang, L. H. Xia, and S. D. Liang. Joining of carbon/carbon composite with stainless steel using AgCuTi as brazing alloy and $\mathrm{Nb}$ interlayer. Materials Science and Engineering of Powder Metallurgy, Vol. 16, 2011, p. $442-447$ (in Chinese). 
[105] Zhang, X. Y., F. Q. Zhang, L. H. Xia, and Q. Yu. Effect of joining temperature on residual stress of $\mathrm{C} / \mathrm{C}$ composites and $\mathrm{Cu}$ joints. Zhongguo Youse Jinshu Xuebao, Vol. 22, 2012, pp. 1298-1303 (in Chinese).

[106] Zhang, X. Y. Interfacial stress analysis and structural design for composite and Cu joints. Master's thesis, Central South University, 2012 (in Chinese).

[107] Wang, Z. Y., G. Wang, M. N. Li, J. H. Lin, Q. Ma, A. Zhang et al. Three-dimensional graphene-reinforced $\mathrm{Cu}$ foam interlayer for brazing C/C composites and Nb. Carbon, Vol. 118, 2017, pp. 723-730.

[108] Wang, Z. Y., M. N. Li, J. Ba, Q. Ma, Z. Q. Fan, J. H. Lin et al. InSitu synthesized TiC nano-flakes reinforced $\mathrm{C} / \mathrm{C}$ composite- $\mathrm{Nb}$ brazed joint. Journal of the European Ceramic Society, Vol. 38, No. 4, 2018, pp. 1059-1068.

[109] Centeno, A., G. Pintsuk, J. Linke, C. Gualco, C. Blanco, R. Santamaría et al. Behaviour of Ti-doped CFCs under thermal fatigue tests. Fusion Engineering and Design, Vol. 86, No. 1, 2011, pp. 121-125.

[110] Rosales, C. G., G. Pintsuk, C. Gualco, N. Ordás, I. L. Galilea, J. M. R. Fernández et al. Manufacturing and high heat-flux testing of brazed actively cooled mock-ups with Ti-doped graphite and CFC as plasma-facing materials. Physica Scripta, Vol. T138, Dec. 2009, id. 014062.

[111] Qin, Y. Q. and Z. S. Yu. Effect of brazing parameters on microstructures of $\mathrm{C} / \mathrm{C}$ composite/ $\mathrm{Cu} / \mathrm{Mo} / \mathrm{TC} 4$ brazed joints. Journal of Materials Engineering, Vol. 8, 2012, pp. 78-82 (in Chinese).

[112] Qin, Y. Q. and J. C. Feng. Brazing carbon/carbon composite to TC4 with $\mathrm{Cu}$ and Mo composite interlayers. Materials Science and Engineering A, Vol. 525, No. 1-2, 2009, pp. 181-185.

[113] Ikeshoji, T. T., T. Tokunaga, A. Suzumura, and T. Yamazaki. Brazing of $\mathrm{C} / \mathrm{C}$ composites and Ni-based alloy using interlayer. Materials Science and Engineering, Vol. 61, 2014, id. 012013.

[114] Casalegno, V., Th. Koppitz, G. Pintsuk, M. Salvo, S. Rizzo, S. Perero, et al. Proposal for a modified non-active brazing alloy for joining CFC composites to copper. Composites. Part B, Engineering, Vol. 56, 2014, pp. 882-888.

[115] Lin, X. Q., K. Z. Li, H. J. Li, and F. T. Lan. Joining of surface modified carbon/carbon composites and LAS glass ceramic. Hangkong Xuebao, Vol. 30, 2009, pp. 380-384 (in Chinese).

[116] Ren, X. B., H. J. Li, J. H. Lu, L. J. Guo, J. Wang, and X. R. Song. Influence of interlayer's thickness on strength of joints between LAS glass-ceramic and carbon/carbon composites. Journal of Inorganic Materials, Vol. 26, No. 8, 2011, pp. 847-851 (in Chinese).
[117] Isola, C., M. Salvo, M. Ferraris, and M. A. Montorsi. Joining of surface modified carbon/carbon composites using a bariumaluminum-boro-silicate glass. Journal of the European Ceramic Society, Vol. 18, No. 8, 1998, pp. 1017-1024.

[118] Trendway, W. K., K. M. Prewo, and C. G. Pantano. Fiber-matrix interfacial effects in carbon-fiber-reinforced glass matrix composites. Carbon, Vol. 27, No. 5, 1989, pp. 717-727.

[119] Pantano, C. G., G. Chen, and D. Qi. Interface reactions and wetting in carbon-fiber-reinforced glass matrix composites. Materials Science and Engineering A, Vol. 126, No. 1-2, 1990, pp. 191201.

[120] Lan, F. T., K. Z. Li, H. J. Li, Q. G. Fu, and X. Q. Lin. Vitreous joining of SiC-coated carbon/carbon composites. Materials Letters, Vol. 62, No. 15, 2008, pp. 2347-2350.

[121] Fu, Q. G., F. L. Zhao, H. J. Li, H. Peng, and X. Y. Nan. A multiinterlayer LMAS joint of C/C-SiC composites and LAS glass ceramics. Journal of Materials Science and Technology, Vol. 31, No. 5, 2015, pp. 467-472.

[122] Lin, X. Q., K. Z. Li, H. J. Li, F. T. Lan, and D. M. Zhu. Microstructure and properties of joints of carbon/carbon composites and LAS glass ceramic. Development and Application of Materials, Vol. 23, 2008, pp. 13 (in Chinese).

[123] Qiang, Q., K. Z. Li, Q. M. Gao, Q. Song, and J. Wang. Connection between carbon-carbon composites and LAS ceramic with YAST glass-ceramic reinforced by CNTs. Journal of Solid Rocket Technology, Vol. 33, 2010, pp. 459-462 (in Chinese).

[124] Zhao, F. L., Q. G. Fu, L. Wang, and Y. Liu. Construction of $\mathrm{SiCnw/MAS}$ nanocomposites to strengthen and toughen $\mathrm{C} / \mathrm{C}$ LAS joints. Materials Science and Engineering A, Vol. 703, 2017, pp. 137-143.

[125] Zhao, F. L., Q. G. Fu, L. Feng, and Q. L. Shen. Enhancement of C/CLAS joint using aligned carbon nanotubes prepared by injection chemical vapor deposition. Materials Science and Engineering A, Vol. 650, 2016, pp. 67-74.

[126] Xiong, H. P. and B. Chen. High-temperature Brazing Filler Metals for Ceramic Joining and Interfacial Metallurgy. National Defence Industry Press, Beijing, China, 2014 (in Chinese).

[127] Yu, Q. Joining C/C composite to molybdenum. Master's thesis, Central South University, 2012 (in Chinese). 